\title{
Uluslararası Öğrencilerin Matematik Okuryazarlığı Hakkındaki Görüşlerinin incelenmesi
}

\section{An Examination of International Students' Views on Mathematical Literacy}

\author{
Burçin GÖKKURT ÖZDEMIR ${ }^{\mathbb{D}}$, Doç. Dr., Bartın Üniversitesi, Bartın/Türkiye, gokkurtburcin@gmail.com
}

Nihal DÜZALAN ${ }^{\mathbb{D}}$, Yüksek Lisans Öğrencisi, Bartın Üniversitesi, Bartın/Türkiye, nihalduzalan@gmail.com

Gökkurt Özdemir, B. ve Düzalan, N. (2021) Uluslararası öğrencilerin matematik okuryazarlığı hakkındaki görüşlerinin incelenmesi. Batı Anadolu Eğitim Bilimleri Dergisi, 12 (1), 206-233.

Öz. Bu çalışmanın amacı, uluslararası öğrencilerin matematik okuryazarlığı ile ilgili görüşlerini incelemektir. Araştırmada nitel araştırma desenlerinden durum çalışması yöntemi esas alınmıştır. Araştırmanın çalışma grubunu, bir devlet üniversitesinde öğrenim gören yedi farklı ülkeden 27 uluslararası öğrenci oluşturmaktadır. Çalışma grubu, amaçlı örnekleme yöntemi türlerinden maksimum çeşitleme yöntemi ile seçilmiştir. Veri toplama aracı olarak, altı açık uçlu sorudan oluşan yarı yapılandıııımış görüşme formu kullanılmıştır. Verilerin analizinde nitel veri analiz tekniklerinden içerik ve betimsel analiz teknikleri kullanıımışı̆. Çalışmada ulaşılan bulgular sonucunda uluslararası öğrencilerin matematik okuryazarlık kavramının anlamına ilişkin sınırlı bilgiye sahip olduklarına rastlanmıştır. Çalışmada, matematik okuryazarlığın tüm bireyler için gerekli olduğu görüşünde olan uluslararası öğrenci sayısının fazla, gerekli olmadığı görüşünde olan uluslararası öğrenci sayısının az olduğu görülmüştür. Çalışmanın sonucunda, derslerde bazı öğretim üyelerinin matematik okuryazarlığına dikkat etmesine karşın bazılarının dikkat etmediği belirlenmiştir. Ayrıca öğrencilerin görüşleri doğrultusunda, matematik okuryazarlık düzeylerinin geliştirilmesi amacıyla uluslararası öğrencilere hazırlık gibi lisans derslerini almadan önce eğitim verilmesi, seçmeli derslerin açılması, ödevlerin verilmesi, öğretim üyelerine anlayamadığı durumları rahatıkla sorabilmeleri, öğretim üyelerinin onlara zaman ayırması gibi uygulamaları istedikleri tespit edilmiştir.

Anahtar kelimeler: Matematik okuryazarlık, Öğrenci görüşleri, Uluslararası öğrenciler.

\begin{abstract}
The aim of the study is to examine the views of international students on mathematics literacy. The case study method, one of the qualitative research designs, was used in the study. The study group of the research consists of 27 international students from seven different countries studying at a state university. The study group was selected from the purposeful sampling method with the maximum diversification method. A semi-structured interview form consisting of six open-ended questions was used a data collection tool. Content and descriptive analysis techniques among qualitative data analysis techniques were used in the analysis of the data. As a result of the findings obtained in the study, it was found that international students had limited knowledge about the meaning of the concept of mathematical literacy. In the study, it was observed that the number of international students who think that mathematics literacy is necessary for all individuals is high and the number of international students who think that it is not necessary is low. As a result of the study, it was determined that although some faculty members paid attention to mathematical literacy during the courses, some did not, and therefore international students had difficulty understanding the course. Furthermore, in line with the opinions of the students, it was determined that they want to give education to international students before taking undergraduate courses such as preparation, opening of elective courses, assigning homework, asking faculty members about situations that they cannot understand, and lecturers to spare time for them in order to improve their mathematics literacy levels.
\end{abstract}

Keywords: Mathematics literacy, Students' views, International students. 


\section{Extended Abstract}

Introduction. Mathematical literacy is the skill that covers facts, competence, processes and basic activities of the individual in terms of social and cultural mathematics in order to keep up with today's innovations and developments (Çağırgan Gülten, 2013; Edge, 2009). Mathematical literacy in an educational setting is also defined by the NCTM as "the level of mathematics knowledge that can be used practically in various situations and conditions" (Pugalee, 1999). According to Dossey and McCrone (2007), mathematical literacy is the ability to understand the place and functions of mathematics in the world, to gain precise judgments and to use mathematics on the basis of an individual's needs in his/her daily life. These mathematical skills include a wide range of mathematical operations from a sort of mathematical calculations to thinking of mathematical issues and its comprehension. In mathematical literacy, one is expected to have competence in mathematical contents (Duran, 2011). NCTM design processes and mathematical skills are of great importance in order to gain mathematical literacy, competence on the part of an individual. In addition, it is vital for one to increase a sort of attitude that includes mathematical thinking and the individual's selfconfidence about his/her success in mathematics (Kaiser \& Willander, 2005). In this vein, Çilingir and Dinç Artut (2016) state that one of the basic purposes of mathematics is mathematics literacy. In order to acquire this skill, one needs to establish relationships between concepts and systems, transfer their knowledge to problems in his/her daily life and learn.

Mathematical literacy is expressed in the ILSS (International Life Skills Survey) as all skills, tendencies, knowledge, beliefs and problem solving skills for a potential participation of individuals in many cases they may face in their daily lives (Mathematics Council of the Alberta Teachers' Association (MCATA), 2000). On the other hand, according to Lutzer (2005), mathematical literacy means making sense of written expressions in the language of mathematics and providing communication (as cited in Özgen \& Bindak, 2011). Mathematical literacy is an important concept in mathematics and this skill requires deep vocabulary for students to read and understand mathematics. Similarly, mathematical terms are needed to comprehend, learn and understand mathematics. (Timothy \& Quickenton, 2003). When dealing with mathematical or scientific literacy, one needs to have knowledge about the discourse and practices regarding literacy types. In other words, it includes language skills, vocabulary, cognitive and metacognitive qualities, emotional expressions, technology and tools in order to produce knowledge and communicate in this discipline (Yore, Pimm, \& Tuan, 2007). Mathematical literacy is the skill required for students to keep up with the developments in science and technology, to define mathematical problems, to reason for solving problems and to provide communication (KurtoğluÇolak, 2006). Accordingly, it is concluded that it is necessary for each individual to gain mathematical literacy in the learning process (Jablonka, 2003). In literature review regarding mathematical literacy, studies were usually conducted with Turkish students (Efe-Çetin \& Mert-Uyangör, 2019; Köysüren \& Üzel, 2018), pre-service teachers (Kabael \& Burak, 2016; Topbaş Tat, 2018) and teachers (Bansilal, Webb \& James, 2015) seen, however, no studies with international students living in Turkey was found. Yet, because international students pursue their education away from their home countries, they may need to have this skill even more than those who live in their homelands. All over the world, students take courses that include mathematics knowledge throughout their education lives and face many problems in their daily lives. Therefore, it is considered necessary to determine the mathematical literacy skills of international students and to get their views on mathematical literacy. If the difficulties of these students can be determined, the curriculum can be rearranged to meet their educational needs and contribute to their becoming mathematically literate individuals. In this context, the aim of the study is to examine the views of international students on mathematics literacy.

Method. Since the aim of the study is to determine the difficulties faced by international students, to overcome these difficulties and to overcome the obstacles in depth, the case study method, one of the qualitative research designs, was used. The study group of the research consists of 27 international students from seven different countries studying at a state university. The study group was selected 
from the purposeful sampling method with the maximum diversification method. A semi-structured interview form consisting of six open-ended questions was used as a data collection tool. Four openended questions were prepared using Şefik and Dost's (2016) pre-utilized questionnaire in the interview form. Two other open ended question (which makes the total of 6 questions) to the interview form were added: to evaluate international students' self-mathematical literacy as well as their ideas on to what extent mathematical literacy during their education in Turkey is valued. Content and descriptive analysis techniques among qualitative data analysis techniques were used in the analysis of the data.

Results and Discussion. As a result of the findings obtained in the study, it was found that international students had limited knowledge about the meaning of the concept of mathematical literacy. Although there are international students who stated that not everyone should be mathematically literate, there is a higher proportion of international students who think that mathematics literacy is necessary for all individuals. It was determined that although some faculty members paid attention to mathematical literacy during the courses, some did not, and therefore international students had difficulty understanding the course. Furthermore, in line with the opinions of the students, it was determined that they want to give education to international students before taking undergraduate courses such as preparation, assigning homework, asking faculty members about situations that they cannot understand, and lecturers to spare time for them in order to improve their mathematics literacy. 


\section{Giriş}

Sürekli olarak gelişim gösteren dünyada, yeniliklere ayak uydurabilen, sorumluluk sahibi olan ve ilerleme kaydedebilen bireylere gereksinim duyulmaktadır. Çağdaş toplumlar düzeyine ulaşabilmek için bireylere sadece bilginin aktarılması yeterli olmamaktadır. Bireylerin ulaşabildikleri bilgileri kullanmasının yanında bilgiyi elde etmek için çaba göstermesi de gerekmektedir (Ağgül Yalçın, 2010). İçinde bulunduğumuz bilgi çağı hayat boyu öğrenmeyi zorunlu kılmaktadır dolayısıyla bilgi okuryazarlığı becerisi alışkanlık haline gelmelidir (Polat, 2006). Bireylerin bilgi birikiminden yarar sağlamaları, bilgiyi kullanabilmeleri ve bilgiyi meydana getirmeleri okuryazarlıkla mümkün olmaktadır. Karunaratne (2000) tarafından okuryazarlık "bireyin yaşadığı toplumda hayatını devam ettirebilmesi, toplumun içinde kendisine yetebilecek kadar okuma yazma ve matematiksel işlemleri bilmesi olarak tanımlanmaktadır (Duran, 2011). PISA olarak kısaltılan Uluslararası Öğrenci Değerlendirme Programı (Programme for International Student Assesment) (2012) değerlendirme sonuçlarında okuryazarlık kavramı, öğrencilerin karşılaştıkları problemleri belirleme, yorumlama ve çözme sürecinde öğrencilerin bilgi ve becerilerini kullanma, analiz etme, mantıksal çıkarımlara ulaşma ve iletişim kurma düzeyidir şeklinde ifade edilmektedir (akt. Milli Eğitim Bakanlığı [MEB], 2015). Eğitim Araştırma ve Geliştirme Dairesi Başkanlığı [EARGED], (2010) okuryazarlığı öğrencilerin bilgilerini günlük yaşamda kullanabilmek, mantıksal çıkarımlar yapabilmek, çeşitli durumlarla ilgili problemleri yorumlayabilmek ve çözebilmek için öğrendiklerinden çıkarımlar yapma kapasitesi olarak tarif etmektedir.

Bilginin içselleştirilmesi kadar, yeni okuryazarlık türlerinin oluşturulması da önemlidir (Önal, 2010). Oluşturulan tanımlar, ortamın istenilen amaç doğrultusunda değişim gösterebileceğini ve çeşitli okuryazarlık türlerinin var olabileceğini göstermektedir. (Sanalan, Sülün ve Çoban, 2007). Okuryazarlığın belirlenen amaçlara ve araçlara (Snavely ve Cooper, 1997) ve açığa çıkan bilgilere göre çeşitlendiği ifade edilmektedir (Jones-Kavalier ve Flannigan, 2006). Günlük hayat, bilim ve teknolojideki yenilikler sonucunda yeni okuryazarlıkların tanımlanması intiyacı ortaya çıkmaktadır (Alpan, 2008). Bireylerin, bilim ve teknolojideki seri gelişmeler sonucu bilgi okuryazarı, bilgisayar okuryazarı, sanat okuryazarı, medya okuryazarı, görsel okuryazarı, fen okuryazarı ve matematik okuryazarı olması kaçınılmaz olmaktadır (Güneş ve Gökçek, 2013; Tüzel, 2010). Bu okuryazarlıklar arasında matematik okuryazarlığı öğrencilerin günümüzde yenilik ve gelişimlere ayak uydurabilmesi amacıyla bireyin sosyal ve kültürel anlamda matematiksel açıdan olguları, becerileri, süreçleri ve temel faaliyetlerini kapsayan yetenektir (Çağırgan Gülten, 2013; Edge, 2009).

Matematik okuryazarlığı hakkında çeşitli araştırmacıların yaptığı tanımlar incelendiğinde; okul matematiği standartlarında Ulusal Matematik Öğretmenleri Konseyi tarafından matematik okuryazarlı̆̆ı, "çeşitli durumlarda ve şartlarda pratik olarak kullanılabilen matematik bilgi düzeyi" olarak tanımlamaktadır (National Council of Teachers of Mathematics [NCTM], 2000). Dossey ve McCrone'ya (2007) göre matematik okuryazarlık, matematiğin dünyadaki yerini ve işlevlerini anlayabilme, kesin yargılar elde edebilme ve günlük hayattaki ihtiyaçların durumuna göre matematiğ $i$ kullanabilme becerisidir. Bu matematiksel beceriler, belirli ölçüdeki matematiksel işlemlerin yapılmasından matematiksel düşünmeye ve kavramaya kadar geniş bir alanı içermektedir. Ekonomik İşbirliği ve Kalkınma Örgütü olan OECD (Organisation for Economic Co-operation and Development) (2006), matematik okuryazarlığını bireyin düşünen, inşa eden, eleştiren bir vatandaş olarak bugün ve gelecekte rastlayacağı problemlerin çözümünde matematiksel düşünme ve karar verme süreçlerini kullanarak günlük hayatta matematiğin oynadığı rolü anlama ve bilme potansiyeli olarak ifade etmiştir. Aydoğdu-iskenderoğlu ve Baki (2011) ise, matematik okuryazarlığını matematiğin dünyadaki yerini tanımlamak ve anlamak amacıyla bireysel kapasiteyi kullanmak, matematiği bireysel yaşantılarımızda kullanmak ve kavramak şeklinde belirtmiştir. Bu tanımlar dışında, Pugalee (1999) matematik okuryazarlığı Şekil 1'deki gibi modellemiştir. 


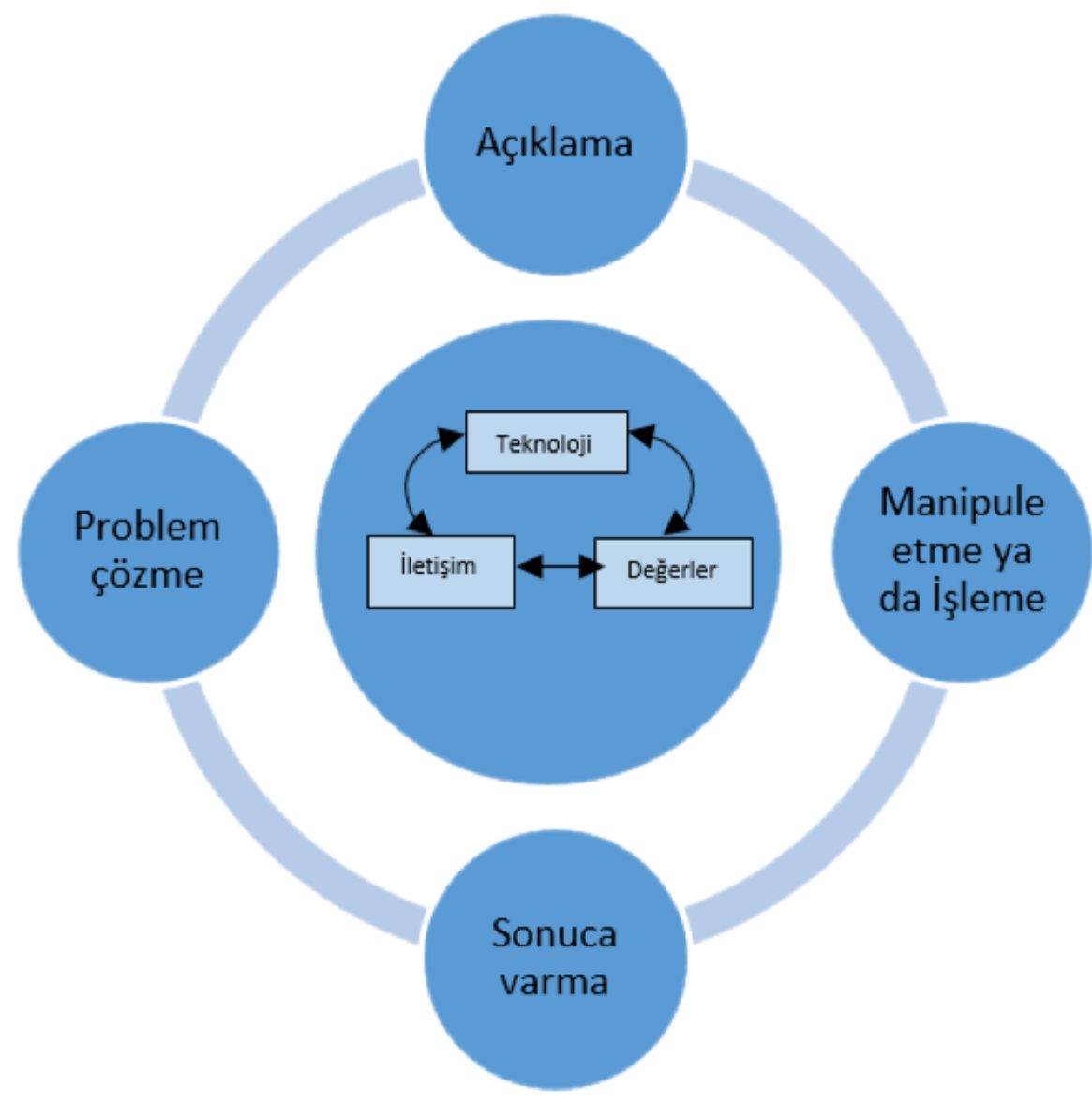

Şekil 1. Matematik okuryazarlık modeli (Pugalee, 1999, s.20)

Şekil 1'de görüldüğü gibi iç çemberde matematiğin çözümünü kolaylaştıran teknoloji, değerler ve iletişimden oluşan üç faktör yer almaktadır. Dış çemberde ise problem çözme, açıklama, işleme ve sonuca varma olmak üzere matematiği çözümlemede kritik olan dört beceri yer almaktadır. Her iki çemberde yer alan öğeler matematik okuryazarlığını kolaylaştırmak ve gelişimini sağlamak amacıyla etkileşim içindedirler.

Matematik okuryazarlığı yeterliğinin sağlanabilmesi için, NCTM tasarı süreçleri ve matematik becerileri kazandırılmalıdır. Ayrıca matematiğe has düşünmeyi içeren bir tutum ve bireyin matematikteki başarısı konusunda özgüveninin artırılması gerekmektedir (Kaiser ve Willander, 2005). Çilingir ve Dinç-Artut da (2016) matematik eğitiminin genel amaçlarından birinin matematik okuryazarlığı olduğunu ifade etmişlerdir. Çalışmalarında, matematik okuryazarlığının, kavramların ve sistemlerin arasında ilişki kurularak öğrenildiğinde ve bilgilerin günlük hayattaki problemler ile öğrenme alanlarına iletildiğinde gerçekleştiği belirtilmektedir. Matematik okuryazarlığı, Alberta Öğretmenler Derneği Matematik Konseyi tarafından yapılan Uluslararası Yaşam Becerileri Anketi'nde (International Life Skills Survey), bireylerin günlük hayatta yüz yüze geldiği sayısal durumlara iyi derecede katılımı için beceri, eğilim, bilgi, inanç ve problem çözme becerilerinin tamamı şeklinde ifade edilmektedir (Mathematics Council of the Alberta Teachers' Association [MCATA], 2000). Lutzer'e (2005) göre matematik okuryazarlık, matematiğin dilindeki yazılı ifadeleri anlamlandırabilme ve iletişimi sağlayabilme anlamındadır (akt. Özgen ve Bindak, 2011). Matematik okuryazarlığı, matematikte önemli bir kavram olup öğrenciler okuma ve anlama için derin kelime hazinesine ihtiyaç duyarlar. Benzer şekilde matematiği kavramak, öğrenmek ve anlamak için de matematiksel terimlere 
intiyaç duyulmaktadır (Timothy ve Quickenton, 2003). Matematiksel okuryazarlık, kişinin okuryazarlık çeşitlerine ilişkin söylem ve uygulamalar hakkında bilgi sahibi olmalarını ve bunları yeterli şekilde kullanmalarını gerektirir. Diğer bir deyişle, bu disipline ait bilgileri üretmek ve iletişimi sağlamak amacıyla dil becerilerini, kelime hazinesini, bilişsel ve üst bilişsel nitelikleri, duygusal ifadeleri, teknolojiyi ve araçları kapsar (Yore, Pimm ve Tuan, 2007). Wardona ve Mariani (2018), matematik okuryazarlık için matematiği çeşitli bağlamlarda formüle etme, uygulama ve yorumlama becerisi olarak ifade etmekte, olayları tanımlamak, açıklamak ve tahmin etmek için matematiksel araçlardan biri olduğunu belirtmiştir. Matematik okuryazarlık yeterliğine sahip bireyler, günlük hayatta karşılaştıkları durumlarda matematik bilgilerini kullanırlar ve makul kararlar verebilirler (Hope, 2007). Bir başka ifadeyle matematik okuryazarlığı, öğrencilerin bilimdeki gelişmelere ve teknolojiye ayak uydurabilmesine, matematiksel problemleri tanımlamasına, problemleri çözerken akıl yürütmesine ve iletişimi sağlamasına yardımcı olur (Kurtoğlu-Çolak, 2006). Matematik okuryazarlık, güncel olaylardaki ve bilimsel gelişmelerdeki matematiksel ilişkileri anlamlandırabilmek açısından da gereklidir (Tekin ve Tekin, 2004). Bireyin, matematiğin gerçek hayattaki önemini fark etmesinde ve önüne çıkan problemlerin üstesinden gelmesinde, matematiksel süreç becerilerini kullanabilmesinde, matematik okuryazarlığının önemi büyüktür (Gellert, 2004). Bu açıdan bakıldığında, her bireye öğrenme sürecinde matematik okuryazarlığı kazandırmanın gerekli olduğu sonucuna ulaşıımaktadır (Jablonka, 2003).

Alanyazın taraması yapıldığında matematik okuryazarlıkla ilgili genelde öğrencilerle (Çetin ve Uyangör, 2019; Köysüren ve Üzel, 2018), öğretmen adaylarıyla (Afifah, Khoiri ve Qomaria, 2018; Ayvaz Can, 2019; Baştürk Şahin ve Altun, 2019; Colwell ve Enderson, 2016; Topbaş Tat, 2018; Kabael ve Burak, 2016) ve öğretmenlerle (Bansilal, Webb ve James, 2015) çalışmaların yapıldığı görülmektedir. Uluslararası literatür incelendiğinde, matematik okuryazarlık üzerine çok fazla çalışmanın olduğu ve farklı ülkelerde matematik okuryazarlığın karşılaştırıldığı çalışmaların da yapıldığı göze çarpmaktadır. Örneğin Berberoğlu ve Güzel (2005), PISA 2000 verilerini dikkate alarak, Brezilya, Japonya ve Norveç'te matematik okuryazarlığını karşılaştırmıştır. Sonuç olarak matematik okuryazarlığı üzerinde en güçlü etkiye sahip gizli bağımsız değişkenin Brezilya'da teknoloji kullanımı, Japonya'da ebeveynlerle iletişim ve Norveç'te okumaya yönelik tutumlar olduğunu tespit etmişlerdir. Gatabi, Stacey ve Gooya (2012) ise Avusturulya ve İran'da iki ülkede dokuzuncu sınıf ders kitaplarını matematik okuryazarlık açısından değerlendirmiş, İran'daki ders kitaplarının yetersiz olduğunu ifade etmiştir. Başka bir çalışmada öğrencilerin dijital medya destekli matematik okuryazarlık becerileri incelenmiş ve araştırmada Sanal Matematik Kitleri (SMK) kullanılmıştır, Araştırmada dijital medya olarak SMK'nın ilkokul öğrencilerinin matematik okuryazarlık yeteneklerini desteklemek için büyük etkiye sahip olduğunu göstermiştir (Pradana, Sholikhah, Maharani ve Kholid, 2020). Mevarech ve Fan (2018), öğrencilerin matematik okuryazarlığının sınıfta nasıl geliştirilebileceği konusuna değinerek, bunu başarma potansiyeline sahip bilişsel-üstbilişsel pedagojik durumlara odaklanmışlardır. Beşinci sınıftan dokuzuncu sınıfa kadar öğrencilerle yapılan boylamsal bir çalışmada, matematik okuryazarlığın akademik başarı yanında bilgi ve iletişim teknolojisi okuryazarlı̆̆ı, bilimsel okuryazarlık, okuduğunu ve dinlediğini anlama gibi farklı alanlarda etkisi olduğunu ortaya koymuşlardır (Holenstein, Bruckmaier ve Grob, 2020).

Yukarıdaki çalışmalarda görüldüğü üzere, pek çok araştırmacının matematik okuryazarlık üzerine çalışmalara ağırlık verdikleri görülmektedir. Türkiye'de matematik okuryazarlık üzerine çalışmaların ağırlıkta olmasına rağmen uluslararası öğrencilerle yürütülen çalışmaya rastlanılamadığı tespit edilmiştir. Özellikle farklı ülkelerde öğrenim gören uluslararası öğrencilerin de bu becerilere sahip olması ve öğrenim süreçleri boyunca bu beceriyi kazanmalarına yönelik fırsatlara sahip olup olmadıklarının araştırılması gerektiği düşünülmektedir. Çünkü dünyanın her yerinde öğrenciler öğrenim hayatları boyunca matematik ve matematik bilgisi içeren derslerle karşılaşmaktadırlar. Günlük yaşamda matematiksel becerilerle ilgili problemlerle sık sık karşılaşmaktadırlar. Bu doğrultuda, matematik okuryazarlık, güncel olaylardaki ve bilimsel gelişmelerdeki matematiksel ilişkileri anlamlandırabilmek açısından gereklidir (Tekin ve Tekin, 2004). Kişisel finans planlama, evde veya bilgisayar ekranında tasarım yapma, istatistiksel bilgi akışını anlayabilme ve eleştirel değerlendirebilme 
ve benzeri durumlar matematik okuryazarlığın temel bir araç olduğu alanlardan sadece birkaçıdır (Steen, Turner ve Burkhardt, 2007). Matematik okuryazarı bir kişi, verileri tahmin edebilir, yorumlayabilir, günlük problemleri çözebilir, sayısal, grafiksel ve geometrik durumlarda mantık yürütebilir ve matematiği kullanarak iletişim kurabilir (Ojose, 2011). Bu doğrultuda, yaşamlarını sorunsuz bir şekilde devam ettirebilmek için uluslararası öğrencilerin de matematik okuryazarı olmaları gerekmektedir. Bu araştırmada uluslararası öğrencilerin matematik okuryazarlık hakkındaki görüşlerinin incelenmesi amaçlanmıştır. Araştırmadan elde edilen sonuçların literatüre katkı sağlayacağı düşünülmektedir. Çünkü Türkiye'nin her yerine hızla yayılan ve sayıları sürekli artan uluslararası öğrencilerin eğitimi güncel bir sorun olarak varlığını devam ettirmektedir. Bu sorunların çözümü için geliştirilecek politikaların belirlenmesine kaynak olabilecek bilimsel çalışmaların yeterli olmadığı görülmektedir. Bu araştırma ile Türkiye'de farklı ülkelerden gelen uluslararası öğrencilerin derslerinde matematik okuryazarlık konusunda yaşadıkları zorluklar ve eksiklikler tespit edilebilecek, bu eksiklikler doğrultusunda öğretim programları uluslararası öğrencilerin matematik okuryazar becerisini kazanmaları yönünde eğitimin ihtiyacını karşılayacak şekilde yeniden düzenlenebilecektir. Böylece karşılaşılan zorlukların üstesinden gelebilmek için çözüm önerileri geliştirilecektir.

\section{Yöntem}

Bu araştırma Türkiye' de lisans ve ön lisans düzeyinde öğrenim gören uluslararası öğrencilerin matematik okuryazarlık kavramının anlamına, bilme düzeylerine, matematik okuryazar olmak için nelerin yapılması gerektiği üzerine görüşlerinin belirlenmesi amacıyla yapılmıştır. Bu araştırma nitel araştırma yaklaşımına dayalı durum çalışması niteliğindedir. Nitel araştırma desenleri, araştırmacılar tarafından üzerinde araştırma yapılan kişilerin sahip oldukları deneyimlerden yararlanma, duygu ve düşüncelerini anlayabilme açısından tercih edilen bir araştırma yaklaşımıdır (Ekiz, 2009). Bu araştırmada, öğrencilerin görüşlerine ilişkin detaylı veri toplandığından ve durum tespiti yapıldığından bu yöntemin kullanılması tercih edilmiştir.

\section{Katılımcılar}

Araştırmanın çalışma grubunu, Batı Karadeniz Bölgesi'nde bulunan bir devlet üniversitesinin çeşitli programlarında öğrenim gören 3 ön lisans ve 24 lisans; 7 farklı ülkeden, 6 kız ve 21 erkek olmak üzere toplam 27 uluslararası öğrenci oluşturmaktadır. Çalışma grubundaki uluslararası öğrencilerin seçilmesinde maksimum veri elde edileceği düşüncesiyle amaçlı örnekleme yöntemi kullanılmıştır. Amaçlı örnekleme, zengin bilgiye sahip olduğu düşünülen durumları derinlemesine inceleme fırsatı vermektedir (Yıldırım ve Şimşek, 2013). Araştırmada amaçlı örnekleme yöntemlerinden maksimum çeşitleme kullanılarak öğrencilerin cinsiyet, ülke, sınıf düzeyi, öğrenim gördükleri program açısından çeşitli olmasına dikkat edilmiştir. Çalışma grubunun demografik özellikleri Tablo 1'de yer almaktadır.

Tablo 1.

Uluslararası öğrencilerin demografik özellikleri

\begin{tabular}{|c|c|c|c|}
\hline & & \multicolumn{2}{|l|}{ Cinsiyet } \\
\hline & & Kız & Erkek \\
\hline \multirow{6}{*}{ Ülke } & Türkmenistan & $\begin{array}{l}6 \\
\left(\ddot{O}_{10,11,18,20,21,27}\right)\end{array}$ & $13\left(\ddot{O}_{1,2,3,4,5,6,7,8,12,13,16,17,19}\right)$ \\
\hline & Afganistan & - & $3\left(\ddot{O}_{14,15,22}\right)$ \\
\hline & Çad & - & $1\left(\ddot{O}_{23}\right)$ \\
\hline & Etiyopya & - & $1\left(\ddot{O}_{24}\right)$ \\
\hline & Nijer & - & $1\left(\ddot{O}_{25}\right)$ \\
\hline & Somali & - & $1\left(\ddot{O}_{26}\right)$ \\
\hline
\end{tabular}




\begin{tabular}{|c|c|c|c|}
\hline & Cibuti & - & $1\left(\ddot{O}_{9}\right)$ \\
\hline \multirow[t]{2}{*}{ Öğrenim Durumu } & Lisans & $5\left(\ddot{O}_{10,18,20,21,27}\right)$ & $\begin{array}{l}19 \\
\left(\ddot{O}_{1,2,3,4,5,6,7,8,9,12,13,14,15,16,17,19,23,24,26)}\right.\end{array}$ \\
\hline & Ön Lisans & $1\left(\ddot{O}_{11}\right)$ & $2\left(\ddot{O}_{22,25}\right)$ \\
\hline \multirow{16}{*}{ Program/Bölüm } & $\begin{array}{l}\text { İlköğretim Matematik } \\
\text { Öğretmenliği }\end{array}$ & $3\left(\ddot{O}_{18,20,21}\right)$ & $6\left(\ddot{O}_{1,2,3,4,6,6}\right)$ \\
\hline & Beden Eğitimi Öğretmenliği & - & 1 (Ög) \\
\hline & Sınıf Öğretmenliği & $1\left(\ddot{O}_{10}\right)$ & - \\
\hline & Bilgisayar Mühendisliği & - & $3\left(\ddot{O}_{12,13,16}\right)$ \\
\hline & Makine Mühendisliği & - & $1\left(\ddot{O}_{14}\right)$ \\
\hline & İnşaat Mühendisliği & - & $1\left(\ddot{O}_{19}\right)$ \\
\hline & İşletme & - & $2\left(\ddot{O}_{23,24}\right)$ \\
\hline & Turizm ve Otel İşletmeciliği & $1\left(\ddot{O}_{11}\right)$ & - \\
\hline & Rekreasyon & - & $1\left(\ddot{O}_{5}\right)$ \\
\hline & İngilizce Tercümanlık & - & $1\left(\ddot{O}_{26}\right)$ \\
\hline & Halkla İlişkiler & - & $1\left(\ddot{O}_{25}\right)$ \\
\hline & Siyaset Bilimi ve Kamu Yönetimi & - & $1\left(\ddot{O}_{7}\right)$ \\
\hline & Yönetim Bilişim Sistemleri & - & $1\left(\ddot{O}_{15}\right)$ \\
\hline & Moleküler Biyoloji ve Genetik & - & $1\left(\ddot{O}_{17}\right)$ \\
\hline & Bilgisayar Programcılığı & - & $1\left(\ddot{O}_{22}\right)$ \\
\hline & Psikoloji & $1\left(\ddot{O}_{27}\right)$ & - \\
\hline \multirow{5}{*}{ Sınıf Düzeyi } & Hazırlık & - & $3\left(\ddot{O}_{3,5,13}\right)$ \\
\hline & 1 & - & $7\left(\ddot{O}_{17,19,22,23,24,25,26}\right)$ \\
\hline & 2 & $\begin{array}{l}6 \\
\left(\ddot{O}_{10,11,18,20,21,27)}\right.\end{array}$ & $6\left(\ddot{O}_{1,2,8,12,14,15}\right)$ \\
\hline & 3 & - & $2\left(\ddot{O}_{7,16}\right)$ \\
\hline & 4 & - & $3\left(\ddot{O}_{4,6,9}\right)$ \\
\hline \multirow{3}{*}{ Yaş } & $19-21$ & $5\left(\ddot{O}_{10,11,18,21,27}\right)$ & $11\left(\ddot{O}_{1,2,3,5,8,13,19,22,23,24,25}\right)$ \\
\hline & $22-24$ & - & $7\left(\ddot{O}_{2,7,12,14,15,16,17,26}\right)$ \\
\hline & $25-27$ & $1\left(\ddot{O}_{20}\right)$ & $3\left(\ddot{O}_{4,6,9}\right)$ \\
\hline
\end{tabular}

Çalışmaya dâhil olan öğrencilerin isimleri araştırmanın etiği gereği gizli tutularak öğrencilere Ö1, Ö2, Ö3, Ö4... Ö27 şeklinde kodlar verilmiştir.

\section{Veri toplama araçları}

Çalışma kapsamında, veri toplama aracı olarak Türkiye'de öğrenim gören ön lisans ve lisans düzeyindeki uluslararası öğrencilerin matematik okuryazarlı̆̆ı ile görüşlerini tespit etmek için altı açık uçlu sorudan oluşan yarı yapılandırılmış görüşme formu kullanılmıştır. Veri toplama aracı hazırlanmadan önce ilgili araştırmacılar tarafından alanyazın taranmıştır. Şefik ve Dost'tan (2016) yararlanılarak dört açık uçlu soru hazırlanmıştır. Araştırma konusuna uygun olarak uluslararası öğrencilerin kendi matematik okuryazarlıklarını değerlendirmeleri ve Türkiye'deki öğrenim hayatlarında matematiksel okuryazarlığa ne kadar dikkat edildiği hususunda iki açık uçlu soru daha eklenmiştir. Bu soruların kapsam geçerliğini sağlamak amacıyla, Matematik Eğitimi alanında bir uzman, Milli Eğitim Bakanlığı'nda ve özel okulda görev yapan iki matematik öğretmenine, konu içeriği ve dilin anlaşılıılığı açısından görüşleri alınarak gerekli düzenlemeler yapılmıştır. Uzman görüşleri doğrultusunda görüşmede daha derinlemesine cevaplar alabilmek gerekçesiyle ikinci soruya matematik okuryazarlığı düzeylerini içeren OECD'nin (2009) tanımladığı 8 özgün yeterlik eklenmiştir. 
Bu yeterlikler: Düşünme ve akıl yürütme (muhakeme), Problem oluşturma ve çözme, Araçları kullanma, Sembolik, formal ve teknik dil ve işlemleri kullanımı, İletişim, Modelleme, Temsil ile Gösterim, Tartışma ve irdelemedir. Öğrencilere bu yeterliklerin içeriği açıklanarak hangisi ya da hangilerine sahip oldukları sorulmuştur.

Uygulamaya başlamadan önce araştırmacı tarafından uluslararası öğrencilere uygulama sürecinde anlaşılmayan terim, cümle ve soruların açıklanabileceği vurgulanmıştır. Matematik Okuryazarlığına Iliş̧kin Görüş Formu'nun (MOiGF) kullanışlılı̆ını görmek ve araştırmacının deneyim kazanması için üç öğrenciyle pilot uygulama yapılmıştır. Pilot uygulama sonunda uluslararası öğrencilerin OECD (2009) yeterliklerinin çoğunun ne anlam ifade ettiğini anlayamadıkları ve ikinci soruya ilişkin cevap vermekten kaçındıkları görülmüştür. Asıl uygulama için öğrencilere görüşme sürecinde bu yeterliklerin içeriğinin detaylı yazılı olduğu Tablo 2'deki metin verilmiş ve gerektiğinde örnekler üzerinden anlatılmışır.

Tablo 2.

Matematiksel yeterliklerin içeriği (OECD, 2003'ten akt. Demir, 2015)

\begin{tabular}{|c|c|}
\hline $\begin{array}{l}\text { İletişim } \\
\text { (Anlama ve } \\
\text { Ifade Etme) }\end{array}$ & $\begin{array}{l}\text { - Matematiksel içeriğe sahip konuları yazılı veya sözlü, çeşitli yollarla } \\
\text { kendi kendine ifade etmeyi ve başkalarının bu gibi konularda yazılı } \\
\text { veya sözlü ifadelerini anlamayı içerir. }\end{array}$ \\
\hline $\begin{array}{l}\text { Düşünme ve Akıl } \\
\text { Yürütme }\end{array}$ & $\begin{array}{l}\text { - Matematik sorularının karakteristik özelliklerini ortaya çıkarmayı } \\
\text { (“Var mı..?”, "Eğer varsa kaç tane?”, "Nasıl } \\
\text { buluruz ...?”) } \\
\text { - } \quad \text { Farklı ifadeleri birbirinden ayırmak (tanım, teorem, varsayım, hipotez, } \\
\text { örnekler, şarta bağlı iddialar) } \\
\text { - Verilen matematiksel kavramın kapsamını, sınırlarını anlamak ve ele } \\
\text { almak gibi matematiğin sunduğu çeşitli cevapları bilmeyi içerir. }\end{array}$ \\
\hline $\begin{array}{l}\text { Tartışma ve } \\
\text { Argümantasyon }\end{array}$ & $\begin{array}{l}\text { - Matematiksel ispatların diğer matematiksel akıl yürütmelerden nasıl } \\
\text { farklı olduğunu } \\
\text { - Farklı türlerde matematiksel ispatların takip edilmesini ve } \\
\text { değerlendirilmesini } \\
\text { - Deneye dayalı sezgilere sahip olmayı (“Ne olabilir, ne olamaz? ve } \\
\text { neden?”) } \\
\text { - Matematiksel kanıtları oluşturmayı ve ifade etmeyi } \\
\text { içerir. }\end{array}$ \\
\hline Modelleme & $\begin{array}{l}\text { - Modellenen olay ya da durumu yapılandırmayı } \\
\text { - } \text { - Merçeği matematiksel yapılara dönüştürmeyi } \\
\text { - Matematiksel modelleri gerçeklik açısından yorumlamayı } \\
\text { - Modeli doğrulamayı } \\
\text { - } \text { Bir modeli yansıtmayı, çözümlemeyi } \\
\text { - Modele ve onun sonuçlarına eleştiri sunmayı } \\
\text { - Model ve sonuçları hakkında (sonuçların sınırlılıkları dâhil) konuşmayı } \\
\text { - Modelleme sürecini izlemeyi ve kontrol etmeyi içerir. }\end{array}$ \\
\hline $\begin{array}{l}\text { Problem } \\
\text { Oluşturma } \\
\text { ve Çözme }\end{array}$ & $\begin{array}{l}\text { - Soru halinde ortaya koymayı } \\
\text { - Formüle etmeyi } \\
\text { - Farklı türlerde matematiksel problemleri tanımlamayı (örneğin, } \\
\text { " "pür", "uygulamalı", "açık uçlu”, "kapalı" ) } \\
\text { - Farklı türlerde matematiksel problemleri farklı yollarla çözmeyi içerir. }\end{array}$ \\
\hline $\begin{array}{l}\text { Temsil ile } \\
\text { Gösterim }\end{array}$ & $\begin{array}{l}\text { - Çözmeyi, şifrelemeyi, çevirmeyi, yorumlamayı, matematiksel nesne } \\
\text { ile durumların temsilinin farklı biçimlerini ve çeşitli temsillerin } \\
\text { birbirleriyle aralarındaki ilişkileri ayırt etmeyi } \\
\text { - Duruma ve amaca göre farklı biçimlerde temsilleri seçmeyi ve } \\
\text { aralarında değiştirmeyi içerir. }\end{array}$ \\
\hline
\end{tabular}




\begin{tabular}{lll}
\hline Sembolik, & $\bullet$ & $\begin{array}{l}\text { Sembolik ve biçimsel dili çözmeyi, yorumlamayı ve onun doğal dille } \\
\text { Formal ve }\end{array}$ \\
$\begin{array}{l}\text { Teknişkisini anlamayı } \\
\text { ve İşlemleri }\end{array}$ & $\bullet$ & Doğal dilden sembolik/biçimsel dile çevirmeyi \\
Kullanma & $\bullet$ & $\begin{array}{l}\text { Formül ve sembolleri içeren anlatım ve ifadeleri kullanmayı, } \\
\text { değişkenleri kullanmayı, denklemleri çözmeyi ve hesaplamaları } \\
\text { yürütmeyi içerir. }\end{array}$ \\
\hline Araçları & Matematiksel etkinliğe yardımcı olacak çeşitli araçları (teknoloji \\
Kullanma & $\begin{array}{l}\text { araçları dâhil) kullanabilmeyi ve böyle araçların sınırılıklarını bilmeyi } \\
\text { içerir. }\end{array}$ \\
\hline
\end{tabular}

Uygulama, 2019-2020 eğitim öğretim yılı güz döneminde gerçekleştirilmiştir. Uygulama için ilk aşamada 34 uluslararası öğrenciye ulaşımıştır. Öğrencilerle iletişimde yaşanan sıkıntıdan ve öğrencilerin gönüllü olmamasından dolayı üç uluslararası öğrenci ile görüşmeler yarıda bırakılmıştır. Dört uluslararası öğrencinin sorulara verdikleri cevaplar evet ya da hayır şeklinde olmasından ve istenilen veri doygunluğuna ulaşılamadığından çalışma grubuna dâhil edilmemiştir. Bu kapsamda araştırmada 27 uluslararası öğrenciden elde edilen veriler dikkate alınmıştır. Uygulamada ön lisans ve lisans düzeyinde öğrenim gören uluslararası öğrencilerin her birine MOiGF'deki sorular yarı yapılandırılmış görüşme tekniği ile uygulanmıştır. Görüşme sürecinde öğrencilerin anlatmak istediklerini doğru yorumlayabilmek adına öğrencilerden yaptıkları sözlü açıklamaları yazmaları istenmiştir. Görüşmeler katılımcıların izinleri doğrultusunda ses kaydına alınmıştır. Çalışmanın uygulama sürecinde her uluslararası öğrenci için yaklaşık 40 dakikalık bir görüşme yapılmıştır.

\section{Verilerin analizi}

Bu çalışmada verilerin analizi için hem içerik analizi hem de betimsel analiz yöntemi kullanılmıştır. Verilerin analizi sürecinde ilk önce görüşmelere ait ses kayıtları bilgisayar ortamına aktarılarak ses dökümleri çıkarılmıştır. Sonrasında kodlama sürecinde veri kaybının olmaması ve kodlamanın güvenirliği için öğrencilerin yazılı dokümanlarından elde edilen verilerle, ses dökümleri birlikte paralel bir şekilde incelenerek taslak kodlar çıkarılmıştır. Taslak kodlar, bir bütün olarak değerlendirilerek anlamlı birimlere diğer bir deyişle temalara ve alt temalara dönüştürülmüştür. Kodlamalar oluşturulurken uluslararası öğrencilerin matematik okuryazar kavramının anlamı, bu kavrama sahip olma özelliği ve kendisine kazandırdığı avantajlar ve dezavantajlar, matematik okuryazarlığın önemi, öğretim üyelerinin derslerde bu beceriyi kullanma durumu ve bu becerinin geliştirilmesine yönelik görüşleri tema alınmıştır.

Birinci soruya ilişkin verilerin kodlanmasında Şefik ve Dost (2016) tarafından hazırlanan matematik okuryazarlığı kavramının anlamına yönelik kodlamalardan (Matematiği okuma-yazma/ Matematik dilini kullanma, Matematiği anlama, açıklama, yorumlama/ Matematiğe yönelik olumlu tutum/ Günlük yaşamla ilişkilendirme/ Matematik problemi çözme/ Analiz, sentez, değerlendirme/ Matematiksel düşünme/ Matematiksel bilgi birikimi) yararlanılarak betimsel analiz yöntemi kullanılmıştır. İkinci soruda benzer şekilde OECD'nin (2009) tanımladığı sekiz özgün yeterlik tema olarak alınarak betimsel analiz yapılmıştır. Geriye kalan dört soruda, öğrencilerin görüşleri içerik analizine tabi tutularak çalışmanın amacına yönelik temalar ve alt temalar çıkarılmıştır. Ayrıca uluslararası öğrencilerin tüm sorulara ait görüşlerinden doğrudan alıntılara yer verilmiştir. Veri analizi sürecinde matematik eğitimi alanındaki uzmanın kodları inceleyip değerlendirmesi doğrultusunda kodlar tekrar düzenlenmiştir. Örneğin yapılan düzenlemelere örnek olarak tüm kodlar arasında ifade olarak uyumu sağlamak için "Matematik okuryazar olduğumu düşünüyorum" ifadesi "Matematik okuryazar olduğunu düşünme" şeklinde değiştirilmiştir. Ayrıca uzman görüşü doğrultusunda ikinci soruda OECD’nin (2009) tanımladığı sekiz özgün yeterlik tema olarak alınmıştır. Düzenlenen kodlara göre bir araştırmacı ve bir uzman tarafından veriler ayrı ayrı analiz edilmiştir. Miles ve Huberman'a (1994) göre uzmanın ve araştırmacının kod uyuşum yüzdesi \%96 olarak hesaplanmıştır. Farklılık gösteren temalar ve alt temalar için tekrar bir araya gelinerek ortak karara varılmış ve \%100 uyuma ulaşılmıştır. 


\section{Bulgular ve Yorum}

$\mathrm{Bu}$ bölümde, uluslararası öğrencilerin matematik okuryazarlı̆ı̆na ilişkin görüşlerine yer verilmiştir. Araştırmanın amacına uygun olarak elde edilen veriler belirlenen tema ve alt temalara ayrılarak tablolar halinde sunulmuştur. Bazı tablolarda verilen frekans (f) sayısı katılımcı sayısını değil görüş sayısını belirmektedir. Çünkü farklı temalarda birden fazla görüş bildiren öğrenciler vardır. Bu nedenle bazı tablolarda frekans sayısı katılımcı sayısından fazladır.

Tablo 3.

Uluslararası öğrencilerin matematik okuryazarlığının anlamına ilişkin görüşlerine ait temalar ve alt temalar

\begin{tabular}{|c|c|c|c|c|}
\hline Tema & Alt Temalar & Alt Temaların İçeriği & $\mathbf{f}$ & $\%$ \\
\hline \multirow{9}{*}{ 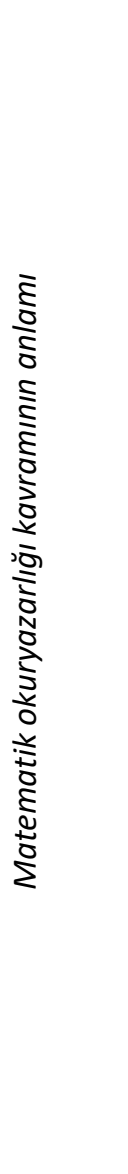 } & Matematiği okuma-yazma & Sembolleri anlayabilme; okuma-yazma & 3 & 5.56 \\
\hline & Matematik dilini kullanma & $\begin{array}{l}\text { Sembolleri kullanabilme; problemi } \\
\text { matematiksel terimlerle ifade } \\
\text { edebilme }\end{array}$ & 5 & 9.26 \\
\hline & $\begin{array}{l}\text { Matematiği anlama, } \\
\text { açıklama, yorumlama }\end{array}$ & $\begin{array}{l}\text { Matematikle ilgili bir şeyi okurken } \\
\text { anlayabilme; yorumlayabilme; } \\
\text { uygulayabilme }\end{array}$ & 6 & 11.11 \\
\hline & $\begin{array}{l}\text { Matematiğe yönelik olumlu } \\
\text { tutum }\end{array}$ & $\begin{array}{l}\text { Matematiği sevme; öğrenme ihtiyacı } \\
\text { duyma }\end{array}$ & 6 & 11.11 \\
\hline & $\begin{array}{l}\text { Günlük yaşamla } \\
\text { ilişkilendirme }\end{array}$ & $\begin{array}{l}\text { Günlük hayatı matematikle } \\
\text { ilişkilendirme }\end{array}$ & 9 & 16.66 \\
\hline & Matematik problemi çözme & $\begin{array}{l}\text { Matematik problemlerini çözebilme; } \\
\text { sayısal işlem yapabilme; çözüme } \\
\text { kavuşturma }\end{array}$ & 12 & 22.22 \\
\hline & $\begin{array}{l}\text { Analiz, sentez, } \\
\text { değerlendirme }\end{array}$ & $\begin{array}{l}\text { Kanıt ve analiz yapabilme; kavramlar } \\
\text { arasında ilişki kurabilme }\end{array}$ & 7 & 12.96 \\
\hline & Matematiksel düşünme & $\begin{array}{l}\text { Problemlere anlayarak yaklaşma; bakış } \\
\text { açısı geliştirme }\end{array}$ & 3 & 5.56 \\
\hline & Matematiksel bilgi birikimi & $\begin{array}{l}\text { Konulara hâkim olma; yeterli } \\
\text { donanıma sahip olma }\end{array}$ & 3 & 5.56 \\
\hline
\end{tabular}

Tablo 3'te uluslararası öğrencilerin matematik okuryazarlı̆ı kavramının anlamına ilişkin görüşlerine yer verilmiştir. Buna göre öğrenci görüşlerinin yaklaşık olarak dörtte birinin (\%22) matematiksel problemleri çözme ve sayısal işlemleri yapabilme, ardından \%16.66' sının matematiği günlük yaşamla ilişkilendirmesi, \%12.96'sının ise analiz, sentez ve değerlendirme becerileriyle ilişkili düşündükleri ortaya çıkmıştır. Tablo 3 'ten en az görüşün matematiğin kendi içindeki yapısına bağlı olarak matematiksel bilgi birikimi, matematiksel düşünme ve matematiksel sembolleri okuma-yazma (\%5.56) olduğu görülmektedir. Öğrencilerin demografik özellikleri dikkate alındığında, öğrencilerin görüşlerinde cinsiyet, öğrenim gördükleri program, sınıf düzeyi ve yaşadıkları ülke bakımından farklılık göstermediği görülmüştür. Örneğin matematik okuryazarlığını matematik dilini kullanma alt temasında düşünen öğrencilerin farklı ülkelerden olduğu (Etiyopya, Türkmenistan, Nijer, Somali ve Afganistan) 
görülmektedir. Bu temada ortaya çıkan Ö10'nun görüşmede yazdığı açıklama Şekil 2'de aynen verilmiştir.

(1) Matematik okuryazarlığı kavramından ne anlıyorsunuz?

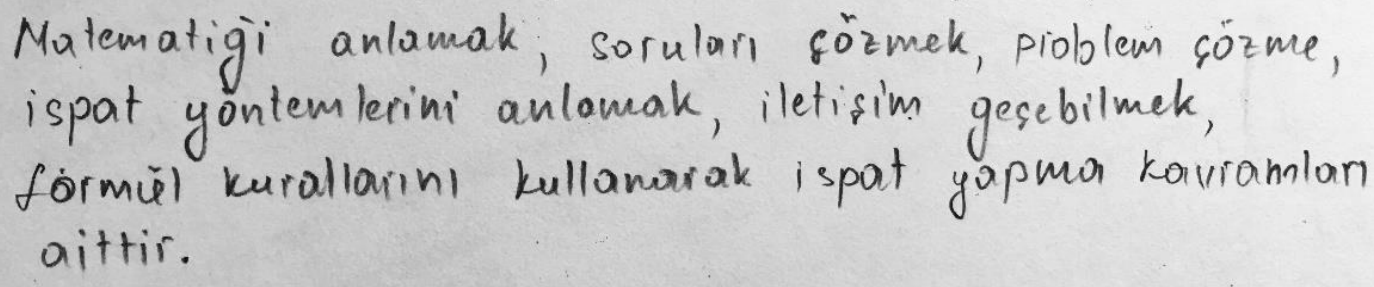

Şekil 2. Ö10 kodlu öğrencinin birinci soruya ilişkin görüşü

Ö10 kodlu öğrenci matematik okuryazarlığı kavramından matematiği ve ispat yöntemlerini anlamayı, formülleri kullanarak kurallar doğrultusunda ispat yapmayı, soru ve problem çözmeyi anladığını belirtmektedir. Şekil 2'de Ö10 kodlu öğrencinin ses kaydına ait veriler incelendiğinde, öğrencinin ses dökümünde "Matematikteki ifadeleri kullanabilme, problem çözme, kanıt ve ispat yapma" ifadeleri yer aldığı için öğrencinin açıklaması, Matematik problemi çözme ve Analiz, sentez, değerlendirme alt temalarına da dâhil edilmiştir. Aşağıda verilen ses dökümüne ait alıntılar bu durumu en iyi şekilde örneklendirmektedir.

\begin{tabular}{l|l|} 
Araştırmacı: Matematik okuryazar kavramından ne anladığını ifade \\
edebilir misin? & $\begin{array}{l}\text { Sembolleri } \\
\text { Ö10: Matematiği anlamaktır. Derste işlem yapabilmektir. Problem } \\
\text { çözmektir. Sınavda ispat yapmaktır. Matematikteki ifadeleri, formülleri } \\
\text { kullanabilme gibi geliyor bana. Formül kurallarını kullanarak ispat yapma } \\
\text { kavramlarına aittir. }\end{array}$ \\
$\begin{array}{l}\text { Araştırmacı: Ifade derken neyi kastediyorsun? } \\
\text { Ö10:Hocalar tahtaya şekiller, semboller yazıyor ya.. }\end{array}$ & $\begin{array}{l}\text { Problem } \\
\text { Cözme } \\
\text { Ispat } \\
\text { Yapma }\end{array}$ \\
\hline araștırmacı: Anladım
\end{tabular}
Araştırmacı: Anladım.

Diğer taraftan Ö23 kodlu öğrencinin birinci soruya ilişkin yazdığı açıklama Şekil 3’te aynen verilmiştir.

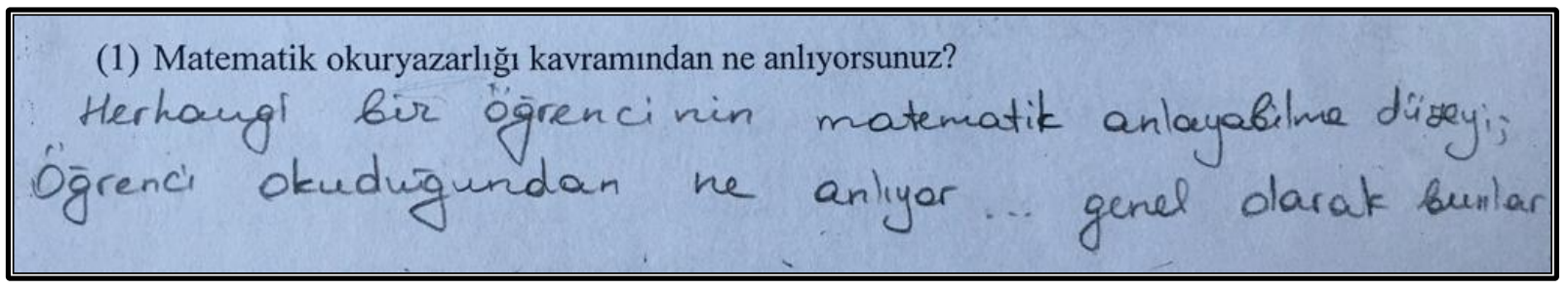

Şekil 3. Ö23 kodlu öğrencinin birinci soruya ilişkin görüşü

Matematik okuryazarlığı Ö23 kodlu öğrenci tarafından herhangi bir öğrencinin matematik anlayabilme düzeyi ve öğrencinin okuduğundan ne anladığı şeklinde ifade edilmiştir. Burada öğrenci matematikle ilgili bir şeyi okurken anlayabilmeyi ve yorumlayabilmeyi kastetmektedir. Bu kapsamda öğrencinin cevabı Matematiği anlama, açıklama, yorumlama alt temasına dâhil edilmiştir. Matematik problemi çözme alt temasında görüş belirten Ö12'nin görüşüne ait alıntı Şekil 4'te sunulmuştur. 
(1) Matematik okuryazarlığı kavramından ne anlıyorsunuz?

Matematile okuryazarligi ogrencilerin sorular, problemalar anlaysp cevap lagabilmeleridir.

Şekil 4. Ö12 kodlu öğrencinin birinci soruya ilişkin görüşü

Ö12 kodlu öğrenciye göre matematik okuryazarlığı öğrencilerin soruları ve problemleri anlayıp cevaplayabilmeleridir. Öğrencinin görüşü içerik olarak matematik problemlerini çözebilme, sayısal işlem yapabilme ve çözüme kavuşturma yönünde oluğundan matematik problemi çözme alt temasına dâhil edilmiştir. Farklı bir alt temada görüş belirten Ö26'nın açıklaması Şekil 5'te verilmiştir.

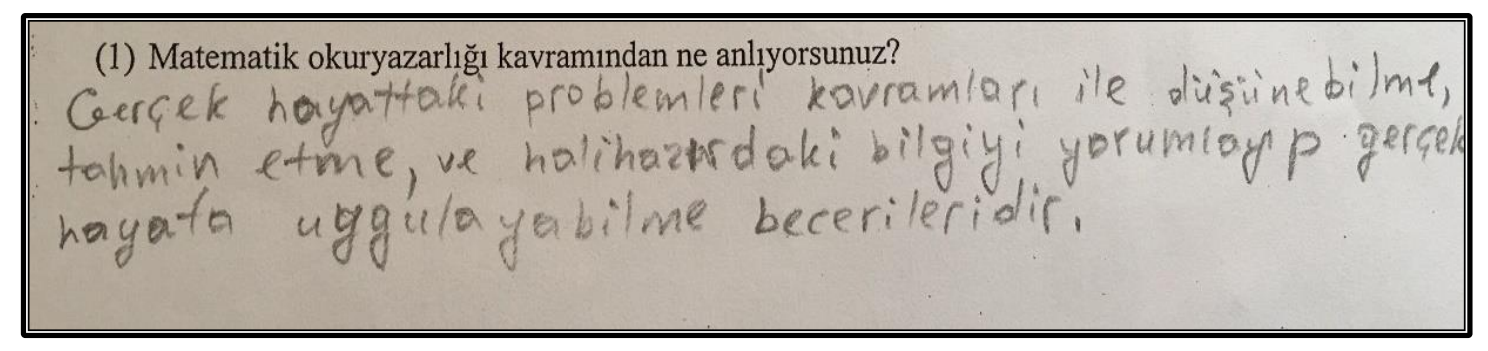

Şekil 5. Ö26 kodlu öğrencinin birinci soruya ilişkin görüşü

Şekil 5'e göre, Ö26 kodlu öğrenci, gerçek hayatı matematikle ilişkilendirme olarak ele almıştır. Bunun sonucunda matematik okuryazarlığını gerçek hayattaki problemleri düşünebilme, tahmin etme ve hali hazırdaki bilgiyi yorumlayıp gerçek hayata uygulayabilme becerisi olarak açıklamaktadır. Öğrencinin görüşme kaydına ait ses dökümü incelendiğinde, bu alt tema dışında farklı bir görüş ileri sürmediği ortaya çıkmıştır. Dolayısıyla öğrencinin görüşü sadece günlük yaşamla ilişkilendirme alt temasına dâhil edilmiştir. Yapılan görüşmelerde bazı öğrenciler matematik okuryazar kavramını ilk kez duyduklarını ve ismine bakarak anlam çıkarmaya çalıştıkları görülmektedir. Aşağıda verilen alıntılar bu durumu açıkça göstermektedir.

"Ö7:...Bu kavramı daha önce duymadım. Isminde matematik okuryazar geçtiğine
göre matematiği okumak herhalde. Matematiği kullanabilme diye
düşünüyorum..."

"Ö23: ...Açıkça ilk kez duydum. Bu kavramı daha önce duymamıştım. Matematik okuryazarı diyorsunuz. İsminde okuryazar geçiyor. Bence okuryazar olması matematiği okuması, anlaması olabilir. Bu nedenle bu şekilde bir tanım yaptım..."

"Ö25:...Matematik okuryazar mı? Böyle bir okuryazarlık mı var. Dijital okuryazarlığı duydum ama bunu duymamıştım. Matematiği kullanabilmek olabilir bence. Matematiksel konuşabilmek...".

Uluslararası öğrencilerin matematik okuryazarı olmalarına ilişkin görüşlerine ait bulgular Tablo 4'te sunulmuştur. 
Tablo 4.

Uluslararası öğrencilerin matematik okuryazarı olmalarına ilişkin görüşlerine ait temalar ve alt temalar

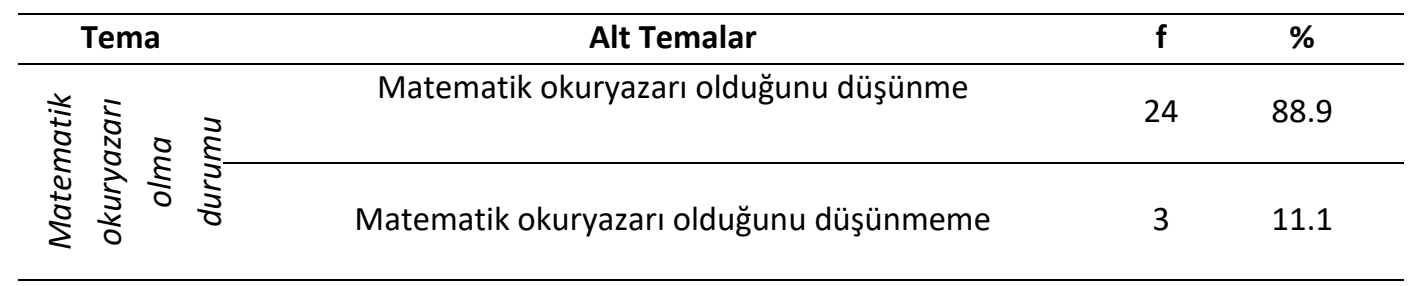

Tablo 4'e göre, uluslararası öğrencilerin büyük çoğunluğu (\%88.9) matematik okuryazarı olduğunu ifade ederken, çok az bir bölümü (\%11.1) matematik okuryazarı olmadığını düşünmektedir. Matematik okuryazar olduğunu düşünmeyen üç erkek öğrenci $\left(\ddot{O}_{5,13,24}\right)$ Türkmenistan ve Etiyopya'da yaşamakta olup, öğrenim gördükleri program Rekreasyon, Bilgisayar Mühendisliği ve iş̧letmedir. Illköğretim matematik öğretmenliği programında öğrenim gören Ö8'in görüşüne ait yazdığı açıklama Şekil 6'da aynen verilmiştir.

(2) Matematik okuryazarı olduğunu düşünüyor musun?

- Cevabın evet ise avantajları neler oldu?

- Pratik dasanmeyr gelistionir

- Dusunnme yetenegine gelistirir.

- Problen córme yeni karsimiza sorun ciukarsa

onunla bes edebilmemiz.

- Gabuk ve dogan düsũnme.

- Bir problemin birkeg gốzünú oldugunu bilmek

Şekil 6. Ö8 kodlu öğrencinin ikinci soruya ilişkin görüşü

Şekil 6’ya göre Ö8 kodlu öğrenci matematik okuryazarı olduğunu düşünmektedir. Öğrenci, matematik okuryazarlığın, pratik, hızlı ve doğru düşünme yeteneğini geliştirmesi, problem çözme becerisi kazandırması, bir problemin birkaç çözümü olduğunu öğrenmesi gibi avantajları olduğunu söylemiştir. Benzer şekilde Ö17, matematik okuryazarı olduğunu, problem çözme becerisi sayesinde zihinsel gelişimini sağladığını ifade etmiştir. Öğrencinin Şekil 7'de verilen açıklaması bunu açıkça göstermektedir.

(2) Matematik okuryazarı olduğunu düşünüyor musun?

- Cevabin evet ise avantajları neler oldu?

Evet, cunnú once problemi yodz sorvyu zatoyip ve förmâtó

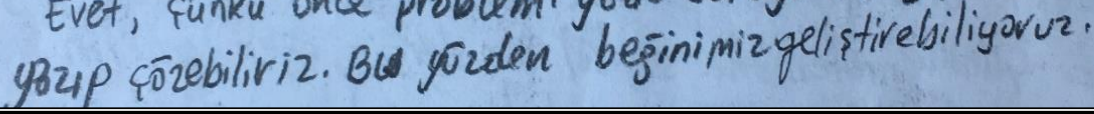

Şekil 7. Ö17 kodlu öğrencinin ikinci soruya ilişkin görüşü

Bu soruyla ilgili olarak farklı görüş belirten Ö14'e ait alıntı Şekil 8'de aynen sunulmuştur. 
(2) Matematik okuryazarı olduğunu düşünüyor musun?

- Cevabın evet ise avantajları neler oldu?

Evet avantajlar hesaplamalar, gözilebilerin Problemleri gözmek. Hesap yaipa bilmek.

Düsümemi gerisdire biliv.

Şekil 8. Ö14 kodlu öğrencinin ikinci soruya ilişkin görüşü

Şekil 8'e göre Ö14 kodlu öğrenci matematik okuryazarı olduğunu bunun sayesinde hesaplamalar yapabildiğini, problem çözebildiğini, düşünmesini geliştirdiğini belirtmiştir. Aynı şekilde okuryazar olduğunu düşünen ve Beden Eğitimi Öğretmenliği programında öğrenim gören, Ö9 ise okuryazar olmanın günlük yaşamda olumlu etkisine vurgu yapmıştır. Bununla ilgili olarak Şekil 9'da Ög’un yazılı açıklaması yer almaktadır.

(2) Matematik okuryazarı olduğunu düşünüyor musun? Evet dü̧ünyarum

- Cevabın evet ise avantajları neler oldu?

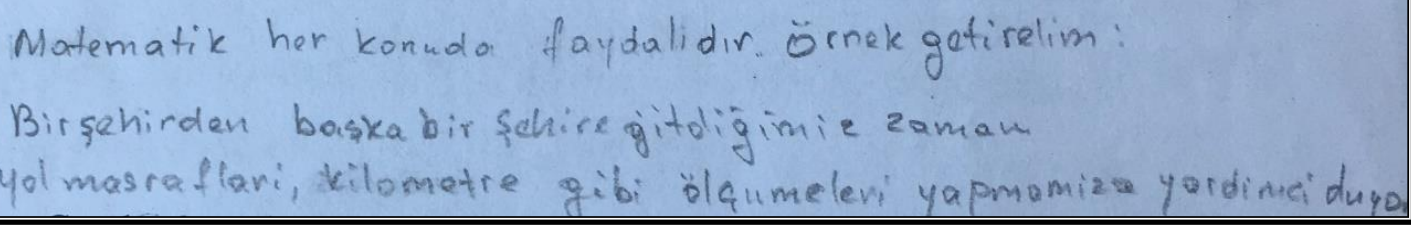

Şekil 9. Ö9 kodlu öğrencinin ikinci soruya ilişkin görüşü

Şekil 9'a göre, Ö9 kodlu öğrenci matematik okuryazarı olduğu görüşündedir. Matematiğin her konuda faydalı olduğunu söylemiştir. Örnek olarak ulaşımla ilgili konularda yol masraflarını belirleme, zamanı ölçme, yol uzunluğunu hesaplayabilme gibi kendisine avantajları olduğunu söylemektedir. Diğer taraftan matematik okuryazar olmadığını düşünen Ö13'ün cevabı Şekil 10'da verilmiştir.

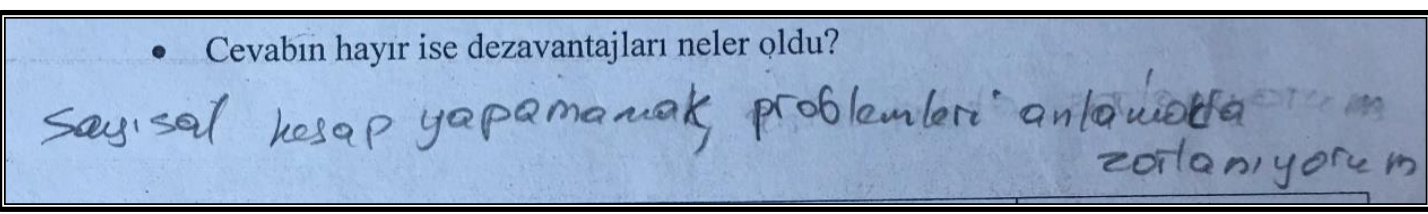

Şekil 10. Ö13 kodlu öğrencinin ikinci soruya ilişkin görüşü

Ö13 kodlu öğrencinin görüşmesine ait ses dökümü incelendiğinde yazılı açıklamasına paralel olarak daha detaylı açıklama yaptığı görülmektedir. Bu soruyla ilgili araştırmacı ve katılımcı arasında geçen diyalog aşağıda verilmiştir. 
Araştırmacı: Matematik okuryazar olduğunu düşünüyor musun?

Cevabın hayır ise dezavantajları neler oldu?

Ö13: Düşünmüyorum. Dezavantaj derken anlamadım.

Araştırmacı: Yani matematik okuryazar olmadığın için zorluk yaşadığın durumlar oldu mu?

Ö13: Evet. Ben Bilgisayar Mühendisliğinde okuyorum. Gerçekten çok zorlanıyorum. Derste bazen de sınavlarda soruları anlayamıyorum. Bazen problemlerin cevabını biliyorum ancak soruyu anlamadığım için yapamıyorum. Sayısal işlem yapamıyorum...

Problemleri

anlayamama

Sayısal

İşlemleri

yapamama

Yukarıdaki diyalogdan da anlaşılacağı üzere, Ö13 matematik okuryazarı olmadığını, sayısal hesaplamalar yapamadığını ve problemleri anlamakta zorlandığını dile getirmiştir. ikinci soruda matematik okuryazarı olduğunu düşünen öğrencilere OECD’nin (2009) tanımladığı sekiz özgün yeterlikten hangisi ya da hangilerine sahip oldukları sorulmuş ve bu soruya ilişkin tema ve alt temalara Tablo 5'te yer verilmiştir.

Tablo 5.

Uluslararası öğrencilerin matematik okuryazarlığı yeterliklerine sahip olmalarına ilişkin görüşlerine ait temalar ve alt temalar

\begin{tabular}{|c|c|c|c|}
\hline Tema & Alt Temalar & f & $\%$ \\
\hline \multirow{8}{*}{ 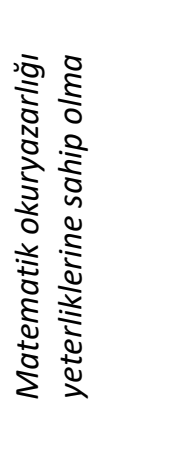 } & Düşünme ve akıl yürütme (muhakeme) & 22 & 81.48 \\
\hline & Problem oluşturma ve çözme & 21 & 77.77 \\
\hline & Araçları kullanma & 20 & 74.07 \\
\hline & Sembolik, formal, teknik dil ve işlemleri kullanımı & 18 & 66.66 \\
\hline & İletişim & 17 & 62.96 \\
\hline & Modelleme & 13 & 48.14 \\
\hline & Temsil & 13 & 48.14 \\
\hline & Tartışma ve irdeleme (Argümantasyon) & 10 & 37.03 \\
\hline
\end{tabular}

Tablo 5 incelendiğinde, uluslararası öğrencilerin matematik okuryazarlığı yeterliklerinden hangilerine sahip oldukları sorulduğunda en fazla oranla (\%81.48) düşünme ve akıl yürütme becerisine sahip oldukları görüşünün ortaya çıktığı görülmektedir. Öğrencilerin demografik özellikleri dikkate alındığında, öğrencilerin yaşadıkları ülke, okudukları program ve sınıf düzeyinin çok etkilemediği, nerdeyse her kesimden bu görüşe sahip olan öğrencilerin olduğu tespit edilmiştir. Bu iki yeterliğin ardından, en çok görüş olarak problem oluşturma ve çözme becerisi (\%77.77), araçları kullanma (\%74.07) ve sembolik, formal, teknik dil ve işlemleri kullanımı (\%66.66) yeterliği ön plana çıkmıştır Öğrenciler bu yeterliklerden en az tartışma ve irdeleme (\%37.03) becerisine sahip olduklarını söylemişlerdir. 
Tablo 6.

Uluslararası öğrencilerin matematik okuryazarlığının gerekliliğine ilişkin görüşlerine ait temalar ve alt temalar

\begin{tabular}{|c|c|c|c|}
\hline Tema & Alt Temalar & $f$ & $\%$ \\
\hline 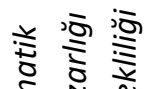 & Gerekli olduğunu düşünme & 22 & 81.49 \\
\hline$\sum_{\substack{0 \\
0}}^{5}$ & Gerekli olduğunu düşünmeme & 5 & 18.51 \\
\hline
\end{tabular}

Tablo 6'daki bulgular, uluslararası öğrencilerin herkesin matematik okuryazarı olmasının gerekli olup olmadığına ilişkin görüşlerine aittir. Tablo 6'ya göre, öğrencilerin büyük bir çoğunluğu (\%81.49) matematik okuryazarlığının gerekli olduğunu belirtmiştir. Özellikle problem çözmeyi öğrenmede ve günlük hayatta matematiği anlamlandırmada, bilimsel çalışmaların yapılabilmesinde gerekli olduğunu ifade etmişlerdir. Bunun aksine beş öğrenci (\%18.51) gerekli olmadığını matematik okuryazarı olmadan da yaşanabileceğini söylemiştir. Olumlu görüş belirten Ö10'nun yazılı açıklaması Şekil 11'de aynen verilmiştir.

(3) Herkes matematik okuryazarı olmalı midır? Nedenini belirtiniz? (Evet) Heikes matematik okuigazari olmalidir. Oknigazar olmadan matematih
ogienemez, matematigin ne oldugiunu, ne etkisi dolugunn, bize neler
yasam ogrenme oitamina ethisini anliyamaz.

Şekil 11. Ö10 kodlu öğrencinin üçüncü soruya ilişkin görüşü

Ö10 kodlu öğrencinin açıklaması incelendiğinde, herkesin matematik okuryazarı olması gerektiğini belirtmiştir. Matematik okuryazarı olmadan matematiğin öğrenilemeyeceğini ifade etmiştir. Ayrıca matematiğin ne olduğunu, öğrenme ortamına etkisini anlayabilmek için matematik okuryazarı olmanın gerekliliğine vurgu yapmıştır. Benzer şekilde olumlu görüş belirten öğrencilerden bazıları bilimsel çalışmalarda matematik okuryazarlığın gerekliliğini ifade ederken, bazıları da günlük hayatta ihtiyaç duyulan bir beceri olduğunu ifade etmiştir. Bununla ilgili olarak Şekil 12 ve 13'te öğrencilerin yazııı açıklamaları yer almaktadır.

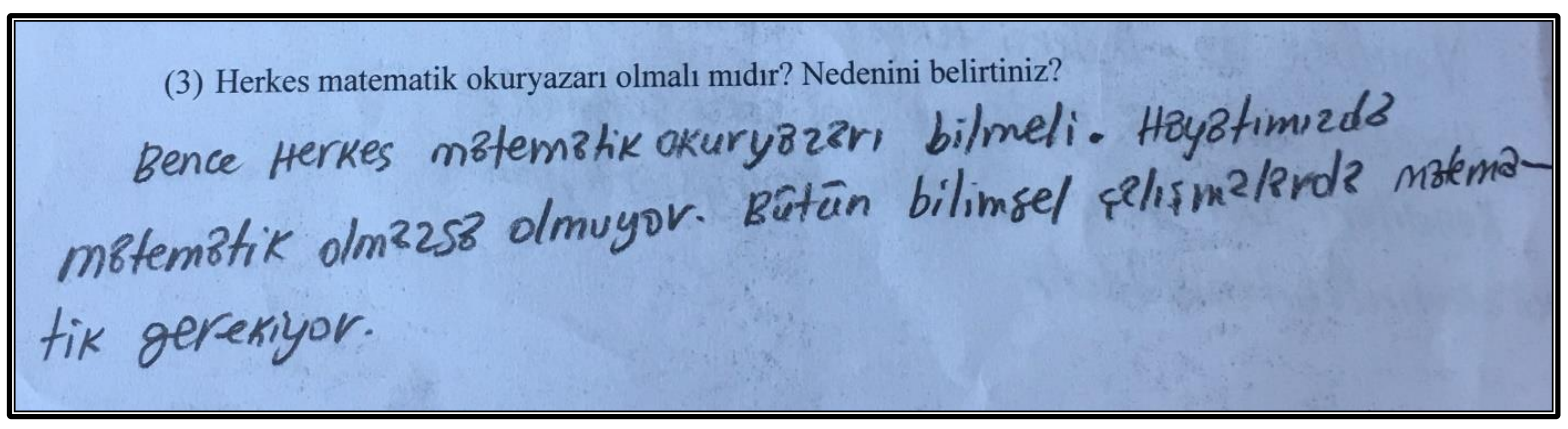

Şekil 12. Ö17 kodlu öğrencinin üçüncü soruya ilişkin görüşü 
Ö17 kodlu öğrenci matematik okuryazarlığının gerekli olduğunu matematiğin hayatımızda olmazsa olmaz olduğunu ve bütün bilimsel çalışmalarda matematiğin gerekli olduğunu söylemiştir.

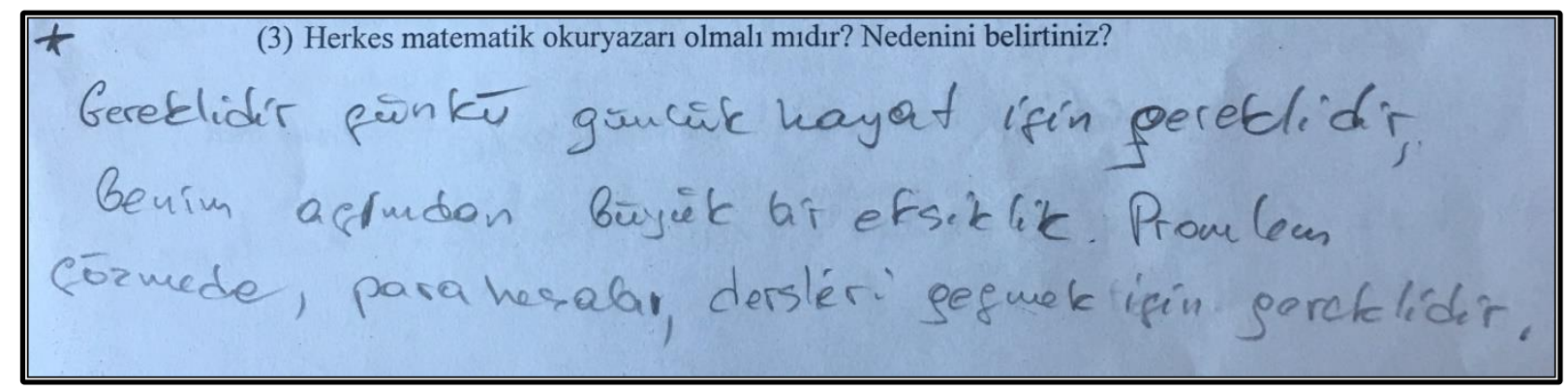

Şekil 13. Ö13 kodlu öğrencinin üçüncü soruya ilişkin görüşü

Ö13 kodlu öğrenci de matematik okuryazarlığının günlük hayat için gerekli olduğunu ancak kendisinin bu konuda eksik olduğunu söylemiştir. Problem çözmede, para hesabında ve derslerde başarı gösterebilmek için herkesin matematik okuryazarı olması gerektiğini belirtmiştir. Olumsuz görüşe sahip olan Ö18 ise gerekçesini Şekil 14'teki gibi belirtmiştir.

(3) Herkes matematik okuryazarı olmalı mıdır? Nedenini belirtiniz?

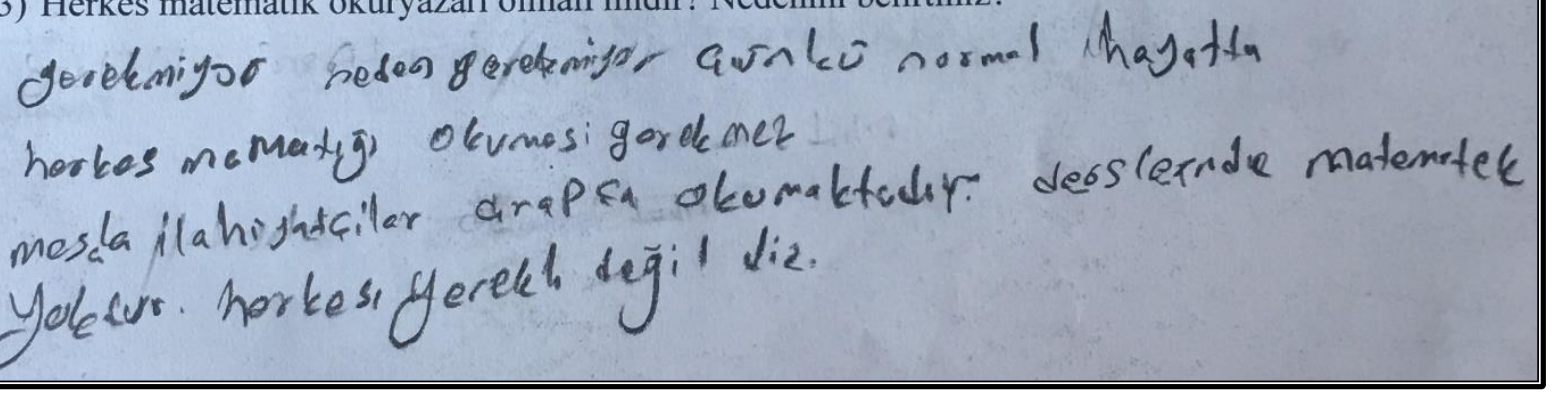

Şekil 14. Ö18 kodlu öğrencinin üçüncü soruya ilişkin görüşü

Ö18 kodlu öğrenci matematik okuryazarlığının gerekli olduğunu düşünmemektedir. Örnek olarak İlahiyat bölümü okuyan öğrencilerin Arapça dersleri aldığını, matematik derslerinin bulunmadığını dolayısıyla matematik okuryazarlığına herkesin sahip olmasına gerek duymadığını dile getirmiştir.

Tablo 7.

Uluslararası öğrencilerin matematik okuryazarı olmanın günlük yaşamda karşılaşılan problemleri çözmedeki etkisine ilişkin görüşlerine ait temalar ve alt temalar

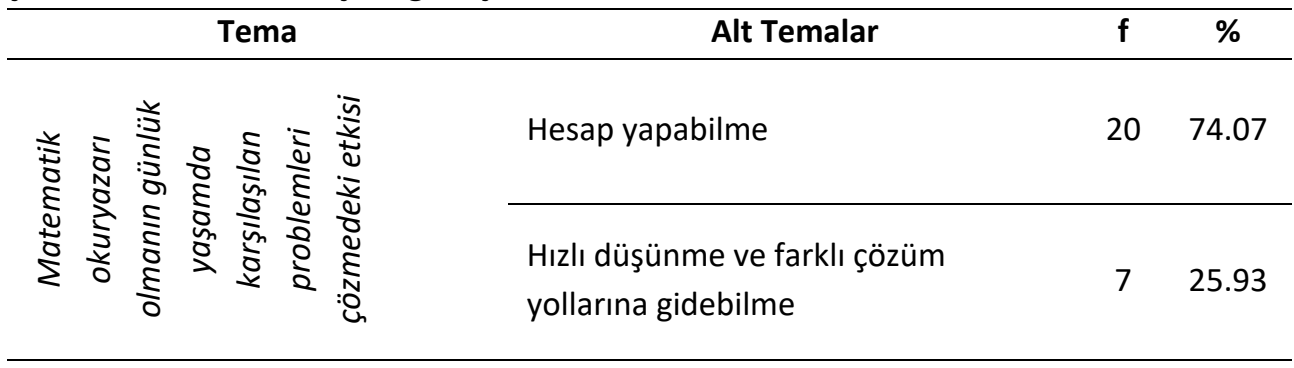


Tablo 7'ye göre, uluslararası öğrencilerin yarıdan fazlasının (\%74.07), matematik okuryazarlığının günlük hayatta en çok hesap yaparken etkisine vurgu yapmışlardır. Görüşmelerde öğrenciler genel olarak matematik okuryazarlık becerisine yeterli düzeyde sahip olunmadığı takdirde, günlük hayatta işlerin aksayabileceğini, olaylar karşısında çözüm üretilemeyeceğini, yaşamı devam ettirmek için engellerin ortaya çıkabileceğini ifade etmişlerdir. Hesap yapabilmeyi zaman hesabı, para hesabı, ulaşım hesabı, derslerdeki başarı durumunu hesaplamak için GNO (Genel Not Ortalaması) hesabı, teknoloji veya endüstride üretim hesabı olarak farklı bakış açılarıyla açıklamışlardır. Diğer taraftan öğrencilerin dörtte biri (\%25.93) ise matematik okuryazarlığına sahip olunursa günlük yaşamda karşılaşılan problemleri çözerken hızlı düşünerek farklı çözüm yollarının elde edilebileceğini dile getirmişlerdir. Farklı görüş belirten öğrencilerden Ö23'ün yazılı açıklaması Şekil 15'te verilmiştir.

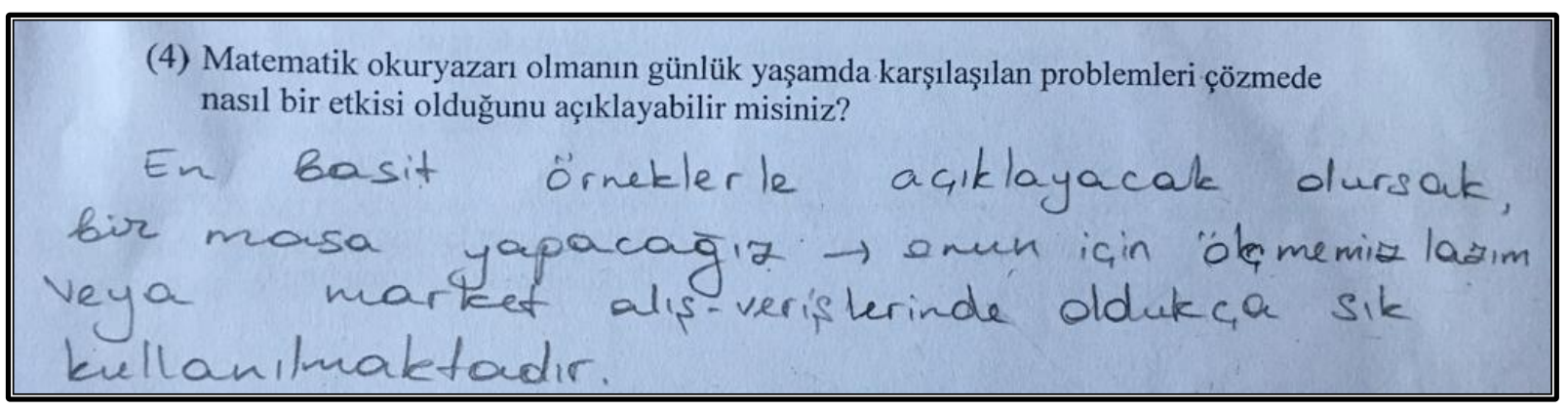

Şekil 15. Ö23 kodlu öğrencinin dördüncü soruya ilişkin görüşü

Şekil 15 incelendiğinde, Ö23 kodlu öğrenci matematik okuryazarı olmanın günlük yaşamda karşılaşılan üretim alanında uzunlukları ölçmede ve market alışverişlerinde hayata etkisinin olabileceğini söylemiştir. Ö12'nin yazılı açıklaması ise Şekil 16'da sunulmuştur.

(4) Matematik okuryazarı olmanın günlük yaşamda karşılaşılan problemleri çözmede nasıl bir etkisi olduğunu açıklayabilir misiniz?

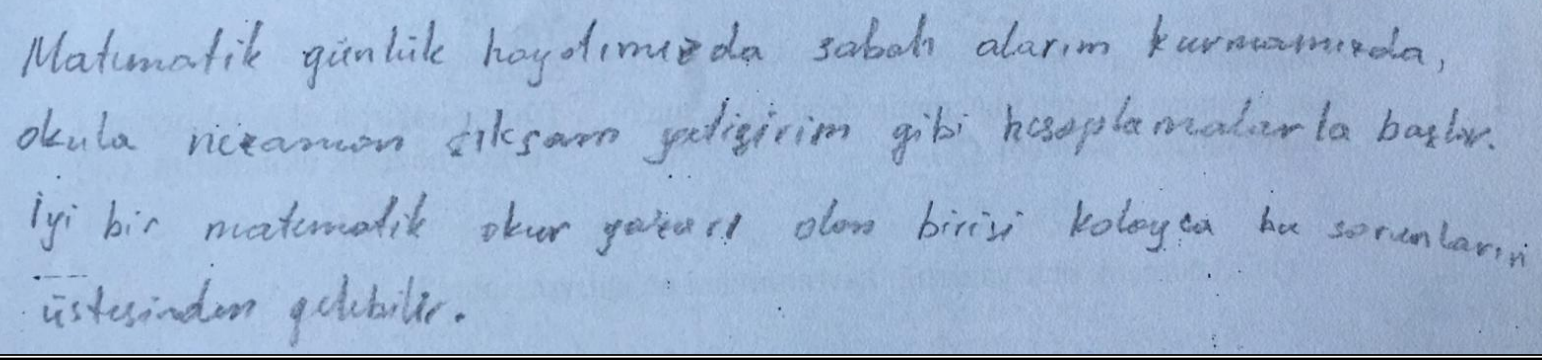

Şekil 16. Ö12 kodlu öğrencinin dördüncü soruya ilişkin görüşü

Ö12 kodlu öğrenciye bakıldığında, matematiğin günlük hayatta kullanıldığını, iyi bir matematik okuryazarı olunursa çeşitli sorunların kolayca çözülebileceğini ifade etmiştir. Zaman hesabı yaparak gidilmesi planlanan yere doğru saatte ulaşmanın amaçlanması gibi günlük hayat problemlerinin çözülebileceğini söylemiştir. Benzer görüş belirten Ö17'nin yazılı açıklaması Şekil 17'de sunulmuştur. 
(4) Matematik okuryazarı olmanın günlük yașamda karșılașılan problemleri çözmede nasıl bir etkisi olduğunu açıklayabilir misiniz?

- Meselo sinavda gec kaldesinda, ne kadar gę ks/disinl ogrenebilir

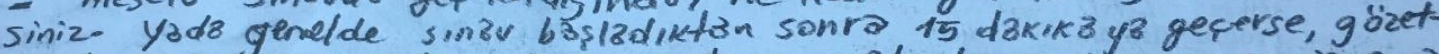

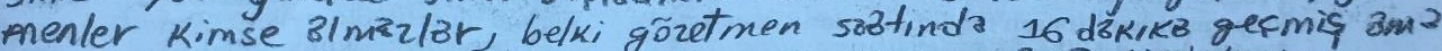
seninkide 14 dzkik8 gefmij, kendini szuenup sinzus girebilirsin

- Bzsk3 bir ülkeye gideceksin, havblimbna gittiginde, sen gef

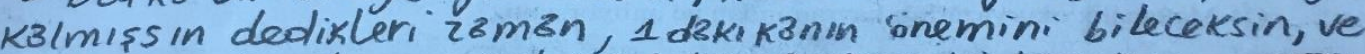

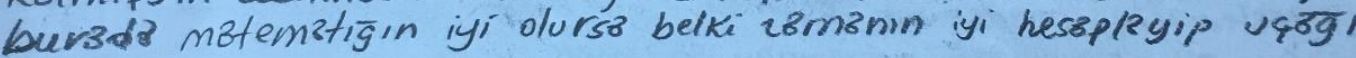
elisirsin.

Şekil 17. Ö17 kodlu öğrencinin dördüncü soruya ilişkin görüşü

Şekil 17'den görüldüğü üzere, Ö17 kodlu öğrenci matematik okuryazarlığının günlük yaşamda karşılaşılan problemleri çözmede zamanı iyi hesaplama ve kullanmada etkisinin olduğunu söylemiştir.

Tablo 8.

Öğretim üyelerinin matematik okuryazarlığına dikkat etme durumlarına ilişkin görüşlerine ait temalar ve alt temalar

\begin{tabular}{|c|c|c|c|}
\hline Tema & Alt Temalar & $F$ & $\%$ \\
\hline \multirow{3}{*}{ 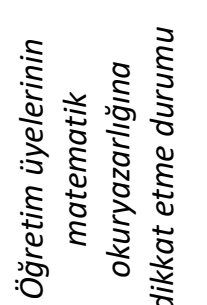 } & $\begin{array}{l}\text { Her zaman } \\
\text { dikkate alma }\end{array}$ & 17 & 62.97 \\
\hline & $\begin{array}{l}\text { Kısmen dikkate } \\
\text { alma }\end{array}$ & 4 & 14.81 \\
\hline & $\begin{array}{l}\text { Hiçbir zaman } \\
\text { dikkate almama }\end{array}$ & 6 & 22.22 \\
\hline
\end{tabular}

Uluslararası öğrencilere "Türkiye' de ön lisans/ lisans öğrenim sürecinizde derslerde öğretim üyeleri tarafından matematik okuryazarlığına dikkat edildiğini düşünüyor musunuz?" şeklinde soru yöneltildiğinde, öğrencilerden \%62.97'si olumlu, \%22.22'si olumsuz ve \%14.81'i kısmen cevapları alınmıştır. Olumlu cevap veren öğrenciler, öğretim üyelerinin derslerde uluslararası öğrencilere ayrıca yardımcı olduğunu, eğitim sistemlerinden kaynaklı akademik farklııklardan dolayı eksiklikler yaşandığında konuyu geçmişe dönük ve tekrar anlattıklarını belirtmişlerdir. Öğrencilerin çoğu ders esnasında konunun anlaşılıp anlaşılmadığını sorarak ya da matematiksel sembollerin ne anlama geldiğini açıklayarak öğretim üyelerinin matematik okuryazarlığına bu şekilde dikkat ettiklerini söylemişlerdir. Olumlu görüşe sahip makine mühendisliğinde öğrenim gören Ö14'ün cevabı Şekil 18'de verilmiştir. 
(5) Türkiye'de lisans öğrenim sürecinizde derslerde öğretim üyeleri tarafindan matematik okuryazarlığına dikkat edildiğini düşünüyor musunuz?

$$
\begin{aligned}
& \begin{array}{l}
\text { Ogretim ayeler: hertangi derslerde yopildik } \\
\text { islemleri sira siro. }
\end{array}
\end{aligned}
$$

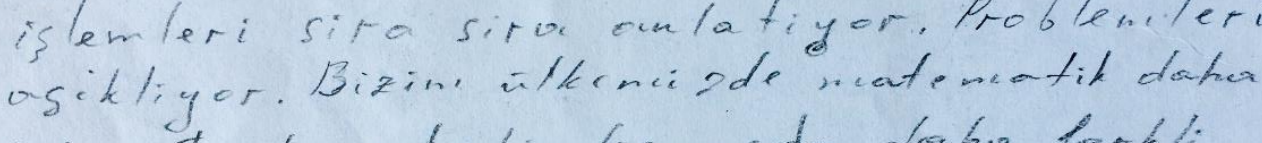

$$
\begin{aligned}
& \text { koloy twakiy daki lisous da olorka farkli }
\end{aligned}
$$

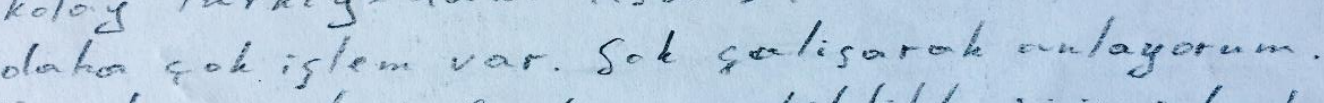

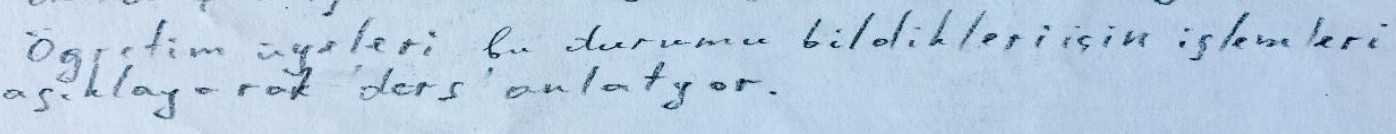

Şekil 18. Ö14 kodlu öğrencinin beşinci soruya ilişkin görüşü

Şekil 18'e göre, Ö14 kodlu öğrenci öğretim üyelerinin derslerde yapılan işlemleri sıra sıra anlattıklarını, problemleri açıkladıklarını söylemiştir. Ülkelerin matematik eğitim düzeyleri farklı olmasından kaynaklı ortaya çıkan sorunları öğretim üyelerinin bildiklerini ve bunun doğrultusunda matematik okuryazarlığına dikkat ettiklerini açıklamıştır. Sınıf öğretmenliği programında öğrenim gören Ö10 da benzer görüşte bulunmuş ve Şekil 19'da görüşünü ayrıntılı olarak yazmıştır.

(5) Türkiye'de lisans öğrenim sürecinizde derslerde öğretim üyeleri tarafından matematik okuryazarlığına dikkat edildiğini düşünüyor musunuz?

$$
\begin{aligned}
& \text { Evet. Hocalarin ders anlatislarinda, sumum yaptirirken, } \\
& \text { soru-cevap tartismasinda, problem cözmede, formü } \\
& \text { kurallarini kultanerken, asiklarken dikkat cdiligor. }
\end{aligned}
$$

Şekil 19. Ö10 kodlu öğrencinin beşinci soruya ilişkin görüşü

Ö10 kodlu öğrenci ders anlatılırken, sunum yaptırıııken, soru cevap, tartışma, problem çözme, formül kullanma durumlarında öğretim üyelerinin yaptıkları açıklamalarla matematik okuryazarlığına dikkat ettiklerini söylemiştir. Olumsuz görüş belirten öğrencilerin nerdeyse tamamı, sınıflarında sayıları az olduğu için öğretim üyelerinin çoğunluğa göre ders yaptıklarını ifade etmişlerdir. Bununla ilgili olarak Bilgisayar Mühendisliği programında öğrenim gören Ö16 ile araştırmacı arasında geçen diyaloğun bir bölümüne yer verilmiştir.

Araştırmacı: Türkiye' de ön lisans/ lisans öğrenim sürecinizde derslerde öğretim üyeleri tarafından matematik okuryazarlığına dikkat edildiğini düşünüyor musunuz?

Ö16: Düşünmüyorum.

Araştırmacı: Neden böyle düşündügünü bize açıklayabilir misin?

Ö16:Ben sınıfta tekim. Hocamız derste direk anlatıyor. Anlayıp anlamadığımızı pek sormuyor. Bazen sınavları bile anlamakta zorlanıyorum. Sınav odaklı olunca da derslerde de bizim üzerimizde çok durulmuyor. Hocanın yanına gidiyorum çalış diyor. Çoğunluğun sorduğu sorulara cevap veriyor. Bence biz az sayıda diye önemsemiyor... 
Tablo 9'da uluslararası öğrencilere matematik okuryazarlığının kazandırılabilmesine ilişkin görüşlerine ait tema ve alt temalar yer almaktadır.

Tablo 9.

Uluslararası öğrencilere matematik okuryazarlığının kazandırılabilmesine ilişkin görüşlerine ait temalar ve alt temalar

\begin{tabular}{|c|c|c|c|c|}
\hline & Tema & Alt Temalar & f & $\%$ \\
\hline \multirow{7}{*}{ 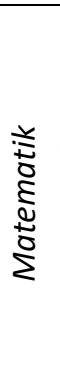 } & \multirow{7}{*}{ 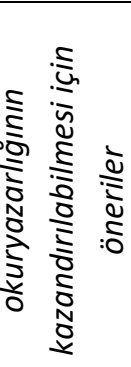 } & Seçmeli ders alma, kursa gitme veya ek ders yapılması & 14 & 51.85 \\
\hline & & Bireysel çalışma/ çabalama & 8 & 29.62 \\
\hline & & Yardım alma & 8 & 29.62 \\
\hline & & Anlatım şekli & 7 & 25.93 \\
\hline & & Motive etme & 5 & 18.51 \\
\hline & & Matematik okuryazarlığının önemini kazandırma & 4 & 14.81 \\
\hline & & Sınıf ortamının düzenlenmesi & 3 & 11.1 \\
\hline
\end{tabular}

Öğrencilerle yapılan bireysel görüşmelerde, uluslararası öğrenciler kendilerine matematik okuryazarlığın kazandırılabilmesi için çeşitli öneriler sunmuştur. Tablo 9'daki bulgular incelendiğinde, en büyük yüzdelik dilime sahip olan görüş \%51.85 ile seçmeli ders alma, kursa gitme veya ek ders yapılması yönündedir. Ardından eşit şekilde bireysel çalışma çabalama (\%29.62) ve yardım alma (\%29.62) gelmektedir. Öğrencilerin \%25.93'ü anlatım şeklinin detaylandırılması, konuyla ilgili daha fazla örnek soru çözülmesi veya konunun günlük hayatla ilişkilendirerek anlatılmasıyla matematiksel okuryazarlığın kazandırılabileceğini düşünmektedirler. Bu soruyla ilgili Ö22'nin yazılı açıklaması Şekil 20 'de aynen verilmiştir.

(6) Matematik okuryazarıı̆ının kazandırılabilmesi için önerileriniz nelerdir?

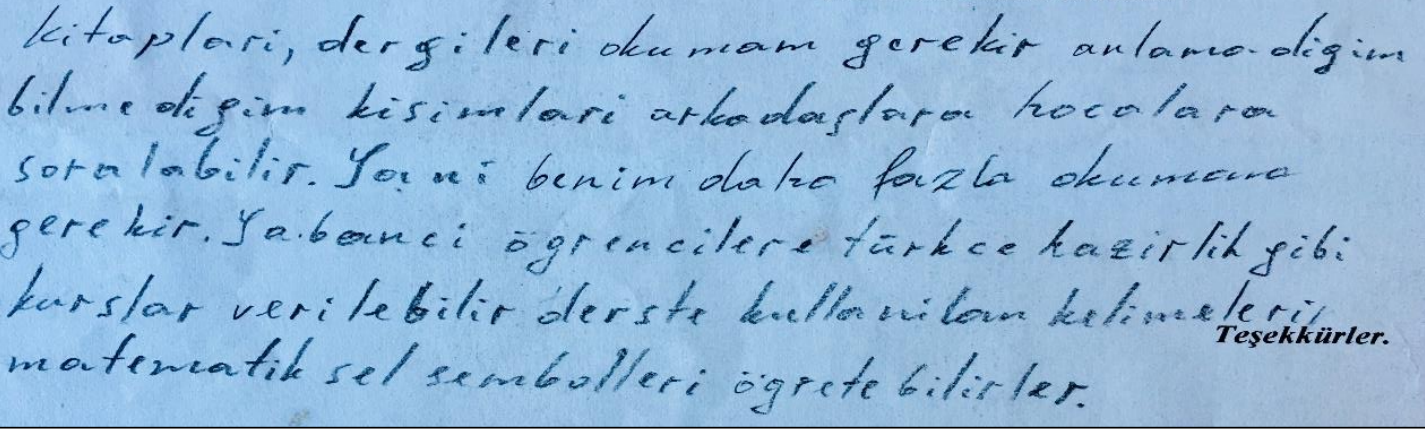

Şekil 20. Ö22 kodlu öğrencinin altıncı soruya ilişkin görüşü

Şekil 20'ye göre, Ö22 kodlu öğrenci matematik okuryazarlı̆ının kazandırılabilmesi için kitap, dergi okumak gerektiğini, bilgisi dışında olan yerleri arkadaşlarına ve öğretim üyelerine sorulabileceğini, kurslara gidilebileceğini ve bu kurslarda matematiği içeren derslerde kullanılan kavram ve sembollerin öğretilebileceğini ifade etmiş̧ir. Farklı görüş belirten Ö19'un cevabı ise Şekil 21'de sunulmuştur. 
(6) Matematik okuryazarlığının kazandırılabilmesi için önerileriniz nelerdir?

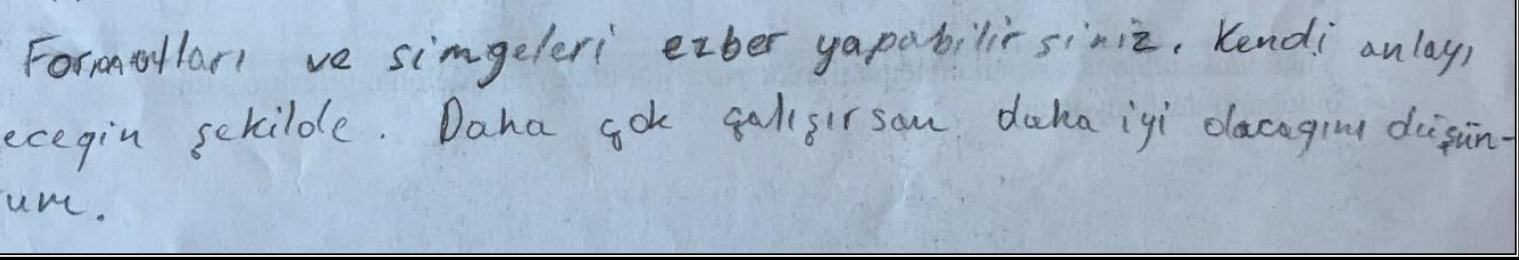

Şekil 21. Ö19 kodlu öğrencinin altıncı soruya ilişkin görüşü

Ö19 kodlu öğrenci matematik okuryazarlığının bireysel çabayla kazanılabileceğini, daha çok çalışma ile formüllerin ve simgelerin zihinde tutulabileceğini ifade etmiştir. Diğer taraftan ö18'in görüşü Şekil 22'de aynen verilmiştir.

(6) Matematik okuryazarlığının kazandırılabilmesi için önerileriniz nelerdir?

$$
\begin{aligned}
& \text { matemasik gosilmesiän onlare gonlük heyethorinde matematikle }
\end{aligned}
$$

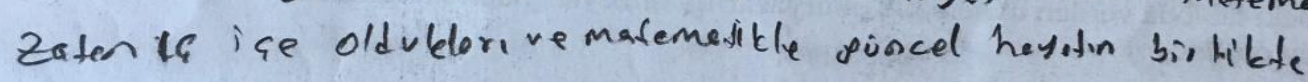

bilinci kacandivilmalidir.

Matemotik esitimailer metemetic olcuryaza lighna diklat felcimoldir

ve ofremle Uzzerinde duramalidir.

Şekil 22. Ö18 kodlu öğrencinin altıncı soruya ilişkin görüşü

Ö18 kodlu öğrenci matematik eğitimcilerinin matematik okuryazarlığına dikkat çekmesi gerektiğini ve matematik okuryazarlı̆̆ının önemi üzerinde durmaları gerektiğini söylemiştir. Matematik okuryazarlığının günlük hayatla iç içe olduğu bilinci kazandırılırsa bireyin matematik okuryazarı olmaya özen göstereceğini belirtmiştir.

\section{Tartışma, Sonuç ve Öneriler}

$\mathrm{Bu}$ araştırmada uluslararası öğrencilerin matematik okuryazarlığına ilişkin görüşleri incelenmiştir. Öğrencilerin sahip oldukları demografik özelliklerinin matematik okuryazarlıkla ilgili görüşlerinde farklılık göstermediği, öğrencilerin demografik özellikleri farklı olsa da benzer açıklamada bulundukları ortaya çıkmıştır. Öğrencilerinin çoğu, matematik okuryazarlık kavramını matematik problemi çözme ve günlük yaşamla ilişkilendirme olarak tanımlamışlardır. Bu bulgulara ek olarak matematiği okuma-yazma, matematik dilini kullanma temasında görüş belirten öğrencilere de rastlanmıştır. Bu sonuç, Şefik ve Dost'un (2016) araştırmasındaki " öğretmen adaylarının çoğu matematik okuryazarlığını matematiği okuma-yazma, matematik dilini kullanma olarak belirtmişlerdir" sonucuyla benzerlik göstermektedir. Araştırmada öğrencilerin çoğunun matematik okuryazarlık kavramını problem çözme ve günlük yaşamla ilişkilendirmelerinin sebebi olarak öğrencilerin günlük hayatta karşılaştıkları durumlarda matematik okuryazar olma ihtiyacı duymaları söylenebilir. Elde edilen bulgularda da öğrencilerin günlük yaşamda alarm kurma, okula gidiş saatini hesaplama, masa yapımı için ölçüm alma, market alışverişi için fiyat tutarını hesaplama ve benzeri durumlarda görüş belirtmeleri bu açıklamayı desteklemektedir. Matematiği okuma-yazma, matematik dilini kullanma olarak görüş belirten bazı öğrencilerin bu şekilde tanım yapmasının sebebi olarak kavramın onlarda çağrıştırdığı anlamı ifade etmeleri olabilir. Yapılan görüşmelerde bazı öğrencilerin bu kavramı ilk kez 
duyduklarını söylemeleri ve kavramın ismine bakarak tanım yapmaya çalışmaları bu durumu en iyi şekilde açıklamaktadır. Matematik okuryazarlık kavramının "Farklı bağlamlarda öğrencilerin matematiği formüle etme, kullanma ve yorumlama kapasitesidir. Bu kapasite, matematiksel muhakeme oluşturabilmeyi ve olguları tanımlamak, açıklamak ve tahmin etmek için matematiksel kavramları, süreçleri, gerçekleri ve araçları kullanabilmeyi içerir (PISA 2012' den akt. MEB, 2011)" tanımı göz önüne alındığında öğrencilerin bu kavramla ilgili doğru açıklamalar yaptıkları ancak bu kavramla ilgili bilgilerinin sınırlı olduğu söylenebilir. Çünkü matematik okuryazar kavramı, matematiği okuma ve yazma ile matematiksel dili kullanmadan daha kapsamlı bir kavramdır.

Araştırmadan elde edilen diğer sonuçlar incelendiğinde, 24 öğrencinin matematik okuryazar olduğunu düşündükleri ve OECD’nin (2009) tanımladığı yeterliklerden en çok düşünme ve akıl yürütme becerisine sahip oldukları en az ise tartışma ve irdelemeye (argümantasyon) sahip olduklarını ifade ettikleri görülmektedir. Öğrencilerin okudukları program dikkate alındığında öğrencilerin matematik okuryazarlığa sahip olma konusunda farklılık göstermediği, İlköğretim Matematik Öğretmenliği programındaki öğrenciler kadar diğer bölümdeki öğrencilerin de ifade ettikleri yeterliklerin benzer olduğu dikkat çekmektedir. Sınıf seviyesi ve cinsiyete göre incelendiğinde, erkek öğrencilerin kendilerinin sahip oldukları yetkinlikler ile kız öğrencilerin sahip oldukları yetkinliklerin benzerlik gösterdiği ortaya çıkmıştır. Birinci sınıfta öğrenim gören öğrenciler ile son sınıfta öğrenim gören öğrencilerin matematik okuryazar olduklarına ilişkin görüşleri de ortaktır. Ancak matematik okuryazar olmadığını düşünen öğrenciler erkek öğrenciler olup, hazırlık $\left(\ddot{O ̈}_{5,13}\right)$ ve birinci sınıfta $\left(\ddot{O}_{24}\right)$ öğrenim görmektedirler. Bu sonuç, literatürdeki bazı çalışmalarla örtüşürken, bazılarıyla farklılaşmaktadır. Örneğin Güneş ve Gökçek (2013), Fen Bilgisi Öğretmenliği ile Sınıf Öğretmenliği programında öğrenim gören öğretmen adaylarının okuryazarlık düzeyleri arasında anlamlı bir ilişkinin olmadığını ifade etmiştir. Diğer taraftan Zehir ve Zehir (2016), dördüncü sınıftaki öğretmen adaylarının matematik okuryazarlık öz-yeterlik inançlarının ikinci sınıftaki öğretmen adaylarının matematik okuryazarlığı özyeterlik inançlarından ve erkek öğretmen adaylarının öz-yeterlik inançlarının kızlarınkinden istatistiksel olarak önemli düzeyde yüksek olduğunu tespit ederek bu çalışmanın sonuçlarıyla farklı bir sonuç elde etmiştir. Altıntaş, Özdemir ve Kerpiç (2012), öğretmen adaylarının matematik okuryazarlık öz-yeterlik algılarının bölümlere ve sınıflara göre farklılaştığını ancak cinsiyete göre farklılaşmadığını ortaya çıkarmışlardır. Araştırma sonunda, yeterlikler arasında tartışma ve irdeleme becerisinin en düşük çıkması, öğrencilerin ileriki öğrenim hayatlarını olumsuz etkileyebilir. Bu yeterliğin içeriğinde matematiksel ispatların diğer matematiksel akıl yürütmelerden nasıl farklı olduğunu düşünme; farklı türlerde matematiksel ispatların takip edilmesini ve değerlendirilmesini yapabilme; deneye dayalı sezgilere sahip olma; matematiksel kanıtları oluşturma ve ifade etme yeterlikleri (OECD 2003'ten akt. Demir, 2015) dikkate alınırsa öğretim üyelerinin derslerde bu yeterliklerin üzerinde durmaları gerektiği önerilmektedir.

Bu çalışmada ortaya çıkan sonuçlardan bir diğeri de bazı öğrencilerin öğretim üyelerinin matematik okuryazarlığa dikkat etmediklerini dile getirmeleridir. Uluslararası öğrencilerin matematik okuryazarlık becerilerini geliştirebilmeleri için çözüm önerisi olarak, matematik okuryazarlık üzerine seçmeli ders alma, bireysel çalışma, öğretim üyeleri tarafından ek ders verme şeklinde ifade ettikleri ortaya çıkmıştır. Ogbu (1992), yabancı uyruklu öğrencilerin akademik eksikliklerini telafi etmek adına matematik gibi dersler için telafi programlarının uygulanmasını önermektedir. Kilpatrick (2001) ise okullarda matematik okuryazarlığın nasıl geliştirileceğine ilişkin bir yaklaşımın belirlenmesi gerektiğine odaklanmaktadır. Mevarech ve Fan (2018), öğrencilerin matematik okuryazarlığının sınıfta nasıl geliştirilebileceği konusuna değinerek, bunu başarma potansiyeline sahip bilişsel-üstbilişsel pedagojik durumlara odaklanmışlardır. Türkiye'de öğretim üyeleri tarafından benzer bir yaklaşım ele alınabilir. Öğretmenlerin, öğrencilerinin matematik okuryazarlığının gelişmesindeki rolü oldukça büyüktür. Dolayısıyla uluslararası öğrencilerin derslerine giren öğretim üyelerinin matematik okuryazarlığının öneminin bilincinde olması ve derslerine girdikleri öğrencilerin matematik okuryazarlığını geliştirmeye yönelik çalışmalar yapmaları büyük önem arz etmektedir. Benzer şekilde Widjaja (2011) ile Altun ve 
Akkaya (2014) çalışmalarında matematik öğretmeni yetiştirme programlarının matematik okuryazarlığını geliştirme yönünde desteklenmesi gerektiğini belirtmektedirler. Kabael ve Barak (2016), Türkiye'de bu gerekliliğin çok önemli boyutlarına dikkat çekmişlerdir.

$\mathrm{Bu}$ araştırma durum çalışması niteliğinde olup, öğrencilerin görüşlerine ilişkin bulgularla sınırıdır. İleride araştırmacıların, uluslararası öğrencilerin matematik okuryazarlık düzeylerini belirleyerek, matematik okuryazarlıklarının geliştirilmesine yönelik çalışmaların yapılması önerilmektedir. Bu araştırmada katılımcı sayısının az olmasından dolayı, ileriki araştırmalarda örneklem sayısının geniş tutularak daha fazla öğrencinin katılımıyla birlikte öğretim üyelerinin de görüşlerinin alınması önerilmektedir. Böylece öğrencilerin matematik okuryazarlık konusunda yaşadıkları zorlukların genelinde belirlenmesi ve bu zorluklar doğrultusunda öğretim programlarının uluslararası öğrencilerin matematik okuryazar becerisini kazanmaları yönünde eğitimin ihtiyacını karşılayacak şekilde yeniden düzenlenmesi gerektiği önerilmektedir. 


\section{Kaynakça}

Afifah, A., Khoiri, M. ve Qomaria, N. (2018). Mathematics preservice teachers' views on mathematical literacy. International Journal of Trends in Mathematics Education Research, 1(3), 92-94.

Ağgül-Yalçın, F. (2010). Ortaöğretim ve yükseköğretim düzeyinde asit-baz konusunun öğretimi için yapılandırmacı yaklaşıma uygun aktif öğrenme etkinliklerinin hazırlanması, uygulanması ve değerlendirilmesi. (Yayımlanmamış doktora tezi). Atatürk Üniversitesi, Fen Bilimleri Enstitüsü, Erzurum.

Alpan, G. (2008). Görsel okuryazarlık ve öğretim teknolojisi. Yüzüncü Yıl Üniversitesi Eğitim Fakültesi Dergisi, 5(2), 74-102.

Altıntaş, E., Özdemir, A. Ş. \& Kerpiç, A. (2012). Öğretmen adaylarının matematik okuryazarlığı özyeterlik algılarının bölümlere göre karşılaştırılması. Trakya Üniversitesi Eğitim Fakültesi Dergisi, 2(2), 26-34. https://dergipark.org.tr/tr/pub/trkefd/issue/21476/230187

Altun, M. ve Akkaya, R. (2014). Matematik öğretmenlerinin PISA matematik soruları ve ülkemiz öğrencilerinin düşük başarı düzeyleri üzerine yorumları. Hacettepe Üniversitesi Eğitim Fakültesi Dergisi, 29(1), 19-34.

Aydoğdu-i̇skenderoğlu, T. ve Baki, A. (2011). İlköğretim 8. sınıf matematik ders kitabındaki soruların PISA matematik yeterlik düzeylerine göre sınıflandırılması. Eğitim ve Bilim, 36(161), 36-161. https://doi.org/10.21764/efd.29539

Ayvaz Can, A . (2019). Sınıf öğretmeni adaylarının matematik okuryazarlığı öz-yeterlik düzeylerinin incelenmesi. Abant Izzet Baysal Üniversitesi Eğitim Fakültesi Dergisi, 19(3) , 753-766 . DOI: 10.17240/aibuefd.2019.19.49440-542414

Bansilal, S., Webb, L. ve James, A. (2015). Teacher training for mathematical literacy: A case study taking the past into the future. South African Journal of Education, 35(1), 1-10.

Baştürk Şahin, B. ve Altun, M. (2019). Matematik öğretmeni adaylarının ürettiği matematik okuryazarlığı problemlerinin matematiksel süreçler bağlamında incelenmesi. Batı Anadolu Eğitim Bilimleri Dergisi, 10(2), 146-161. https://doi.org/10.15285/maruaebd.622149

Berberoğlu, G. ve Güzel, Ç. I. (2005). An analysis of the programme for international student assessment 2000 (PISA 2000) mathematical literacy data for Brazilian, Japanese and Norwegian students. Studies in Educational Evaluation, 31(4), 283-314, https://doi.org/10.1016/j.stueduc.2005.11.006.

Colwell, J. ve Enderson, M. C. (2016). "When I hear literacy": using pre-service teachers' perceptions of mathematical literacy to inform program changes in teacher education. Teaching and Teacher Education. 53, 63-74. https://doi.org/10.1016/j.tate.2015.11.001.

Çağırgan-Gülten, D. (2013). İlköğretim matematik öğretmen adaylarının matematik okuryazarlık öz-yeterlilik inançlarının çeşitli değişkenler açısından incelenmesi. International Online Journal Of Educational Sciences, 5(2), 393-408. https://doi.org/10.30703/cije.656316

Çilingir, E. ve Dinç-Artut, P. (2016). Gerçekçi matematik eğitimi yaklaşımının ilkokul öğrencilerinin başarılarına, görsel matematik okuryazarlığı özyeterlik algılarına ve problem çözme tutumlarına etkisi. Türk Bilgisayar ve Matematik Eğitimi Dergisi, 7(3), 578-600. https://doi.org/10.16949/turkbilmat.277872

Demir, F. (2015). Matematik okuryazarlığı soru yazma süreç ve becerilerinin gelişimi. (Yayınlanmamış doktora tezi). Uludağ Üniversitesi Eğitim Bilimleri Enstitüsü, Bursa.

Dossey, J.A. ve McCrone, S.S. (2007). Mathematical literacy: It's become fundamental. Principal Leadership, 7(5), 32-37.

Duran, M. (2011). İlköğretim 7. sınıf öğrencilerinin görsel matematik okuryazarlığı özyeterlik algıları ile görsel matematik başarıları arasındaki ilişki. (Yayınlanmamış yüksek lisans tezi). Erzincan Üniversitesi Fen Bilimleri Enstitüsü, Erzincan.

Edge, D. L. (2009). Math literacy: The relationship of algebra, gender, ethnicity, socioeconomic status and avid enrollment with high scholl math course completion and college readiness. (Unpublished doctoral dissertation), University of North Texas.

Efe-Çetin, K. ve Mert-Uyangör, S. (2019). 9.sınıf öğrencilerinin matematiksel okuryazarlıklarının akademik başarı ve öğrenme stillerine göre incelenmesi. Necatibey Eğitim Fakültesi Elektronik Fen ve Matematik Eğitimi Dergisi, 13(1) , 48-75. https://doi.org/10.17522/balikesirnef.569430

Eğitim Araştırma ve Geliştirme Dairesi Başkanlığı [EARGED], (2010). PISA 2009 ulus/ararası öğrenci değerlendirme programı ulusal ön rapor, Ankara

Ekiz, D. (2009). Bilimsel araştırma yöntemleri (Genişletilmiş 2.Baskı). Ankara: Anı Yayıncılık 
Gatabi, A.R, Stacey, K. ve Gooya, Z. (2012). Investigating grade nine textbook problems for characteristics related to mathematical literacy. Mathematics Education Research Journal, 24, 403-421. https://doi.org/1007/s13394-012-0052-5.

Gellert, U. (2004). Didactic material confronted with the concept if mathematical literacy. Educational Studies in Mathematics, 55 (s. 163-179). Netherlands: Kluwer Academic Publishers.

Güneş, G. ve Gökçek, T. (2013) Öğretmen adaylarının matematik okuryazarlık düzeylerinin belirlenmesi. Dicle Üniversitesi Ziya Gökalp Eğitim Fakültesi Dergisi, 20 70-79. https://doi.org/10.14582/duzgef.621

Holenstein, M., Bruckmaier, G. ve Grob, A. (2020). Transfer effects of mathematical literacy: an integrative longitudinal study. Eur J Psychol Educ . https://doi.org/10.1007/s10212-020-00491-4.

Hope, M. (2007). Mathematical literacy. Principal Leadership, 7(5), 28-31.

Jablonka, E. (2003). Mathematical literacy. In A. Bishop, C. Keitel-Kreidt, J.Kilpatrick, F.-S. Leung, \& M. Clements, Second International Handbook of Mathematics Education (pp.75-201). Dordrecht: Kluwer Academic Publishers.

Jones-Kavalier, B.R. ve Flannigan, S.L. (2006). Connecting the digital dots: Literacy of the 21st century. In EDUCAUSE Quarterly, 29(2). Erişim adresi (05.10.2019): http://www.educause.edu/EDUCAUSE+Quarterly/EDUCAUSEQuarterlyMagazineVolum/ConnectingtheDi gitalDotsLitera/157395.

Kabael, T. ve Barak, B. (2016). Research of middle school pre-service mathematics teachers' mathematical literacy on PISA items. Turkish Journal of Computer and Mathematics Education (TURCOMAT), 7(2) , 321349. https://doi.org/10.16949/turcomat.73360

Kaiser, G. ve Willander, T. (2005). Development of mathematical literacy: Results of an empirical study. Teaching Mathematics and Its Applications, 24(2-3), 48-60. https://doi.org/10.1093/teamat/hri016

Karunaratne, W. (2000). Case for adult literacy in South East Asia with special reference to Sri Lanka. The Australian Council for Adult Literacy Conference, Perth, Australia, 21-23 September.

Kilpatrick, J. (2001). Understanding mathematical literacy: The Contribution of Research, Educational Studies in Mathematics, 47, 101-116 https://doi.org/10.1023/A:1017973827514

Kurtoğlu-Çolak, S. (2006). Materyal kullanımının altıncı sınıf öğrencilerinin geometri kavramları bağlamında matematiksel okuryazarlığına etkisi üzerine deneysel bir çalışma. (Yayımlanmamış yüksek lisans tezi). Gazi Üniversitesi Eğitim Bilimleri Enstitüsü, Ankara.

Köysüren, M. ve Üzel, D. (2018). Matematik öğretiminde teknoloji kullanımının 6. sınıf öğrencilerinin matematik okuryazarlığına etkisi. Necatibey Eğitim Fakültesi Elektronik Fen ve Matematik Eğitimi Dergisi, 12(2) , 81101 . https://doi.org/10.17522/balikesirnef.506418

Mathematics Council of the Alberta Teachers' Association [MCATA] (2000). mathematics council of the alberta teachers' association (MCATA). Paper on mathematical literacy. Erişim adresi (03.01.2020): http:// www. Pasificlearning. Com.

Mevarech Z.R. ve Fan L. (2018) Cognition, Metacognition, and Mathematics Literacy. In: Dori Y., Mevarech Z., Baker D. (eds) Cognition, Metacognition, and Culture in STEM Education. Innovations in Science Education and Technology, vol 24 (pp. 261-278). Springer, Cham. https://doi.org/10.1007/978-3-31966659-4_12

Milli Eğitim Bakanlığı [MEB] (2011). PISA Türkiye. http://pisa.meb.gov.tr/wp-content/uploads/2013/07/PISAkitab\%C4\%B1.pdf. Erişim tarihi: 03.04.2018

Milli Eğitim Bakanlı̆̆ [MEB] (2015). PISA 2012 araştırması ulusal nihai rapor. http://pisa.meb.gov.tr/. Erişim tarihi: 10.09.2020

National Council of Teachers of Mathematics [NCTM]. (2000). Principles and standards for school mathematics. Reston: NCTM.

Ogbu, J. U. (1992). Understanding cultural diversity and learning. Educational researcher, 21(8), 5-14.

Ojose, B. (2011). Mathematics literacy: Are we able to put the mathematics we learn into everyday use. Journal of Mathematics Education, 4(1), 89-100.

Organisation for Economic Co-operation and Development [OECD], (2009). Learning mathematics for life. PISA, OECD Publishing.

Organisation for Economic Co-operation and Development [OECD], (2006). Assessing scientific, reading and mathematical literacy, a framework for PISA. http://www. oecd.org/ Erişim tarihi: 01.02.2018.

Önal, ì. (2010). Tarihsel değişim sürecinde yaşam boyu öğrenme ve okuryazarlık: Türkiye deneyimi. Bilgi Dünyası, 11(1) 101-121. 
Özgen, K. ve Bindak, R. (2011). Lise öğrencilerinin matematik okuryazarlığına yönelik öz-yeterlik inançlarının belirlenmesi. Kuram ve Uygulamada Eğitim Bilimleri, 11(2), 1073-1089. https://doi.org/10.29299/kefad.2018.20.01.002

Polat, C. (2006). Bilgi çağında üniversite eğitimi için bir açılım: Bilgi okuryazarlığı öğretimi. A.Ü. Türkiyat Araştırmaları Enstitüsü Dergisi, 12(30), 249-266. https://doi.org/10.14222/turkiyat775

Pradana, L., Sholikhah, O., Maharani, S. ve Kholid, M. (2020). Virtual Mathematics Kits (VMK): Connecting Digital Media to Mathematical Literacy. International Journal of Emerging Technologies in Learning (iJET), 15(3), 234-241. Kassel, Germany: International Journal of Emerging Technology in Learning. https://www.learntechlib.org/p/217015/. Erişim tarihi: 07.02.2020

Pugalee, D. K. (1999). Constructing a model of mathematical literacy. The Clearing House 73(1), 19-22.

Sanalan, V.A., Sülün A. ve Çoban, T.A. (2007). Görsel okuryazarlık. Erzincan Eğitim Fakültesi Dergisi, 9(2), 33- 47. https://doi.org/10.17556/erziefd.298455

Snavely, L. ve Cooper, N. (1997). The information literacy debate. The Journal of Academic Librarianship, 23(1), 9-13.

Steen L.A., Turner R. ve Burkhardt H. (2007) Developing mathematical literacy. In Blum W., Galbraith P.L., Henn HW., Niss M. (eds) Modelling and applications in mathematics education. New ICMI Study Series, vol 10. (pp. 285-294). Springer, Boston, MA. https://doi.org/10.1007/978-0-387-29822-1_30.

Şefik, Ö. ve Dost, Ş . (2016). Ortaöğretim matematik öğretmen adaylarının matematik okuryazarlığı hakkındaki görüşleri . Necatibey Eğitim Fakültesi Elektronik Fen ve Matematik Eğitimi Dergisi, 10(2) , 320-338 . https://doi.org/10.17522/balikesirnef.277935.

Tekin, B. ve Tekin, S. (2004, Kasım). Matematik öğretmen adaylarının matematiksel okuryazarlık düzeyleri üzerine bir araştırma. Matematik etkinlikleri 2004: Matematik sempozyumu ve sergileri. Ankara:MATDER.

Timothy, M. ve Quickenton, A. (2005). Effects of preservice teachers' math literacy in a tutorial field experience. International Journal for Mathematics Teaching and Learning. www.cimt.plymouth.ac.uk/.../timothy.pdf. Erişim tarihi: 05.06.2019

Topbaş-Tat, E. (2018). Matematik öğretmen adaylarının matematik okuryazarlığı öz-yeterlik algıları. ilköğretim Online, 17(2), 489-499. https://doi.org/10.17051/ilkonline.2018.418887

Tüzel, M.S. (2010). Görsel okuryazarlık. Türklük Bilimi Araştırmaları, 27, 691-705.

Wardono, S. ve Mariani, S. (2018). The analysis of mathematics literacy on PMRI learning with media schoology of junior high school students. Journal of Physics: Conference Series. 983(1), 1-9. IOP Publishing. https://doi.org/10.1088/1742-6596/983/1/012107.

Widjaja, W. (2011) Towards mathematical literacy in the 21st century: perspectives from Indonesia. Southeast Asian mathematics education journal, 1(1),75-84.

Yıldırım, A. ve Şimşek, H. (2013). Sosyal bilimlerde nitel araştırma yöntemleri (9. Baskı). Ankara: Seçkin Yayıncılık.

Yore, L. D., Pimm, D. ve Tuan , H. L. (2007). The literacy component of mathematical and scientific literacy. International Journal of Science and Mathematics Education, 5, 559-589. https://doi.org/10.1007/s10763007-9089-4

Zehir, K. ve Zehir, H. (2016). İlköğretim matematik öğretmen adaylarının matematik okuryazarlığı öz-yeterlik inanç düzeylerinin çeşitli değişkenler açısından incelenmesi. Uluslararası Eğitim Bilim ve Teknoloji Dergisi, 2(2) , 104-117. https://doi.org/10.14520/adyusbd.27281 